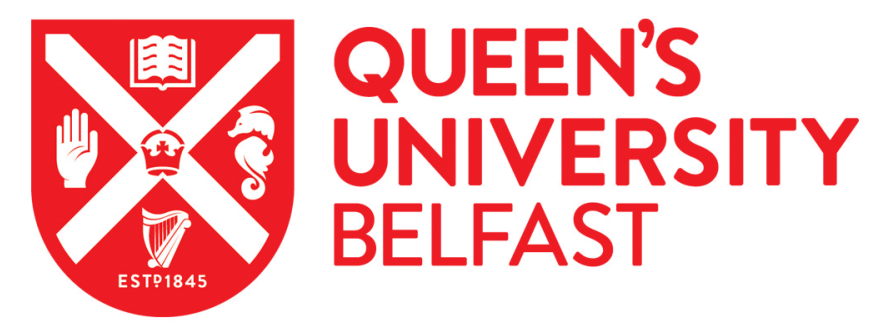

\title{
Assessing life cycle impacts and the risk and uncertainty of alternative bus technologies
}

Harris, A., Soban, D., Smyth, B. M., \& Best, R. (2018). Assessing life cycle impacts and the risk and uncertainty of alternative bus technologies. Renewable and Sustainable Energy Reviews, 97, 569-579.

https://doi.org/10.1016/j.rser.2018.08.045

\section{Published in:}

Renewable and Sustainable Energy Reviews

\section{Document Version:}

Peer reviewed version

\section{Queen's University Belfast - Research Portal:}

Link to publication record in Queen's University Belfast Research Portal

\section{Publisher rights}

Copyright 2018 Elsevier Ltd.

This manuscript is distributed under a Creative Commons Attribution-NonCommercial-NoDerivs License

(https://creativecommons.org/licenses/by-nc-nd/4.0/), which permits distribution and reproduction for non-commercial purposes, provided the author and source are cited.

\section{General rights}

Copyright for the publications made accessible via the Queen's University Belfast Research Portal is retained by the author(s) and / or other copyright owners and it is a condition of accessing these publications that users recognise and abide by the legal requirements associated with these rights.

Take down policy

The Research Portal is Queen's institutional repository that provides access to Queen's research output. Every effort has been made to ensure that content in the Research Portal does not infringe any person's rights, or applicable UK laws. If you discover content in the Research Portal that you believe breaches copyright or violates any law, please contact openaccess@qub.ac.uk. 


\title{
Assessing Life Cycle Impacts and the Risk and Uncertainty of Alternative Bus Technologies
}

\author{
Andrew Harris ${ }^{\mathrm{a}, *}$, Danielle Soban ${ }^{\mathrm{a}}$, Beatrice Smyth $^{\mathrm{a}}$, Robert Best ${ }^{\mathrm{b}}$ \\ aSchool of Mechanical and Aerospace Engineering, Queen's University Belfast, BT9 5AH, United Kingdom \\ bWrights Group Ltd, Ballymena, Co. Antrim, BT42 1PY, United Kingdom \\ *Corresponding author: aharris07@qub.ac.uk (A. Harris)
}

Citation: Harris A, Soban D, Smyth BM, Best R. Assessing life cycle impacts and the risk and uncertainty of alternative bus technologies. Renewable and Sustainable Energy Reviews 2018;97:56979. doi:10.1016/j.rser.2018.08.045.

\begin{abstract}
Low-emission alternative bus technologies are of increasing interest to bus fleet operators due to the reduced environmental impact and potential for lower operating costs. However, with uncertainty regarding the total cost of ownership of new technologies and life cycle impacts beyond the typical well-to-wheel boundary, stakeholders may not have the necessary specific tools or evidence to evaluate life cycle impacts. The aim of this paper is to develop a novel framework to assist decision-makers in assessing the uncertainty of the life cycle impacts of alternative bus technologies. The Technology Impact Forecasting methodology was employed, integrating a life cycle model, to investigate whole life cycle impacts in an exploratory assessment environment, allowing for the analysis and trade-off evaluations of alternative drivetrain technologies and operational scenarios. This research provides a comprehensive novel framework for addressing uncertainty in whole life cycle costs and GHG emissions for the manufacture, use, maintenance and infrastructure phases of diesel and battery electric buses. Eleven scenarios are assessed in the framework, evaluating combinations of battery technologies, well-to-tank pathways, charging infrastructure and auxiliary demands. For every battery electric bus scenario, there is an $80 \%$ confidence that life cycle $\mathrm{GHG}$ emissions are mitigated by $10 \%$ to $58 \%$ compared to the baseline diesel bus, but life cycle costs are $129 \%$ to $247 \%$ higher. Opportunity charged electric buses employing a lithium-titanate battery are the most effective scenario for mitigating GHG emissions per additional cost of the new technology to the operator. The framework highlights a key trade-off between dependence on battery capacity and high-power charging infrastructure for battery electric bus technologies. The framework enables stakeholders to make technology adoption and resource allocation decisions based on the risk of a scenario and provides a level of confidence in a technologies' ability to mitigate whole life cycle impacts.
\end{abstract}

\section{KEYWORDS}

Risk and Uncertainty, Technology Impact Forecasting, Life Cycle Assessment, Life Cycle Costing, GHG Emissions, Alternative Bus Fleets. 


\section{INTRODUCTION}

\subsection{Background}

The 2015 Paris Agreement signalled a global commitment to mitigate the effects of climate change caused by anthropogenic greenhouse gas (GHG) emissions [1]. The EU has also committed to reducing GHG emissions by $80-95 \%$ by 2050 compared to 1990 levels [2]. The transport sector is responsible for $25 \%$ of EU GHG emissions [3], and as part of measures to address this emissions standards have been introduced for heavy duty vehicles, e.g. Euro VI legislation [4]. For large operators of heavy duty vehicles, such as bus fleets, the need to conform to environmental legislation is steering interest towards low emission vehicles. However, market penetration of alternative technologies, e.g. battery-electric buses (BEB), is hindered by higher acquisition costs compared to conventional diesel vehicles [5-7]. There are also concerns about the total cost of ownership (TCO) with uncertainty regarding additional infrastructure, maintenance routines and the sensitivity to energy costs [5-10].

Stakeholders seeking to employ alternative driveline technologies need to evaluate both economic and environmental effects. However, the many factors in a vehicle life cycle lead to high levels of variation in whole life cycle impacts reported in literature, both for a specific technology and when comparing multiple technologies (Figure 1 and 2). Although a decreasing trend can be observed in whole life cycle GHG emissions with increased electrification, there is wide variation in the results, and there is no clear trend for whole life cycle costs versus technology type. Such variation leads to uncertainty when comparing alternative technologies. To assist in this complex decision-making process, there is a need for a rapid assessment environment to evaluate whole life cycle environmental and economic impacts of alternative bus driveline technologies (and varying operational conditions) and to quantify the potential uncertainty and assess key sensitivities of the vehicle life cycle.

\subsection{Aim and Focus of Paper}

The aim of this paper is to develop a novel framework to assist decision-makers in assessing the uncertainty of the life cycle impacts of alternative bus technologies. This paper focuses on conventional Euro VI diesel and theoretical battery electric bus technologies. A BEB provides a good case study; in terms of the degree of vehicle electrification, conventional diesel and battery-electric vehicles are on contrasting ends of the scale [30]. Some knowledge of alternative propulsion systems is assumed and will not be covered in this paper, as many review studies cover these topics extensively, e.g. [7,31-35]. Note that the concepts of risk and uncertainty can differ depending on the field of research e.g. economics [36]. In the context of this paper, uncertainty is a state of limited knowledge, where possible states or outcomes can be quantified by assigning probabilities to these states or outcomes [37]. Risk is therefore the quantified probability of an outcome occurring [37]. 


\subsection{Life Cycle Modelling of Bus Technologies}

Life cycle analysis (LCA) methods (Table 1) are typically used to compare alternative technologies. There are three common types of LCA: process-based, economic input-output (EIO-LCA) and a combination of the two, hybrid-LCA. Process-based LCA considers the inputs (energy, materials, etc.) and resultant outputs (emissions, waste, products, etc.) of each unit process over a product's life cycle i.e. a bottom-up approach [38]. EIO-LCA uses monetary transactions between economic sectors to characterise the product's supply chain, including all direct and indirect impacts i.e. a top-down approach [39]. EIO-LCA has the potential for use in a design process, but a hybrid-LCA approach is recommended if more precision is required [40]. Although hybrid-LCAs can still include truncation errors inherent in EIO-LCAs, they can yield a more complete set of results than a single modelling approach [41].

In the context of buses, lack of available component data (e.g. bill of materials) is often cited as a reason why bottom-up studies don't consider the manufacturing phase in life-cycle modelling studies $[14,15]$. Hybrid-LCAs can provide the additional fidelity of process-based methods for key sections of a product's life cycle, e.g. the WTW phase [28], with EIO-LCA methods covering the product's raw material extraction and fabrication. Previous work has tended to use EIO-LCA data for standard components [21,42], while process based LCA has been combined with EIO-LCA results to quantify the impacts from the addition or replacement of specific items, e.g. battery $[9,17]$. The literature review highlighted the following key findings/recommendations regarding the set up a hybrid-LCA bus model:

- The use of aggregated process-based WTT inventories from literature or model databases [43,44] is prevalent in many studies, where the quantifiable environmental impact is used as a model input and not mapped for specific pathways [11,12,16,19-21,45-47]. However, WTT environmental impacts are highly location specific and can vary with time, for example the GHG impacts of electric vehicles are dependent on grid composition, which can fluctuate daily and change significantly annually $[7,48]$. To be of relevance to stakeholders, it is therefore important that life cycle inventories reflect specific geographical and time-related variations.

- Although life cycle impacts can be significantly affected by operational factors, such as auxiliary loads $[14,15,20,46]$ and drivetrain component replacement frequency $[5,6,11,17,24,25,49]$, many models use static inputs of fuel economy $[13,17,21,23,42,50]$ and battery replacements [9$11,17,46]$. However, other research has used vehicle simulation models that are sensitive to varying input parameters to predict the fuel or energy consumption, costs and emissions criteria over a drive cycle $[5,6,11,14,46,49]$. Further developments have integrated the simulation models into life cycle models to calculate battery replacements $[5,6,49]$. The use of formulation-approach mathematical models, reflective of how urban buses are used in service, will ensure an appropriate level of modelling fidelity. 
- With all LCAs it is important to avoid double counting. This is of particular concern in the quantification of the environmental impacts associated with scheduled repair and maintenance as there is relatively limited literature on the subject $[9,10,17,18,46,51]$. Previous work used hybrid LCA, but the methodology has not been fully developed and double counting was apparent. Caution is advised to ensure system boundaries are consistent for maintenance and repair as well as all other stages of the life cycle.

- Although WTW assessment is a sound scientific methodology for comparing alternative drivelines, it can be considered a 'narrow point of view' as it excludes the impacts of raw material extraction and processing, manufacturing, and decommissioning of the vehicle itself [28]. Of the bus life cycle modelling studies reviewed, only four consider the economic impacts of use, acquisition/manufacturing, maintenance and infrastructure phases [15,24,46,49] and only one study considered environmental impacts of the same system boundary phases [17]. The inclusion of the 'equipment life cycle' provides a more comprehensive mapping of the vehicle's environmental impact and can highlight high impact contributing factors in the life cycle of new technologies, e.g. battery manufacturing for electric vehicles [52].

\subsection{Assessing Risk and Uncertainty of Alternative Bus Technologies}

Uncertainty can be addressed by conducting sensitivity analysis to find 'critical' factors of importance to analysts [29]. Incorporating probabilistic techniques (e.g. Monte Carlo simulation [53]) and 'whatif' analysis can further produce a range of possible scenario outcomes [29]. Probabilistic techniques can enhance the understanding of complex comparisons between diesel and electric vehicles [54], but are uncommon in bus life cycle studies; previous research evaluates fuel economy inputs [9] or the acquisition cost, fuel consumption, fuel price and maintenance costs influencing TCO [8]. One methodology that facilitates sensitivity, probabilistic and 'what-if" analyses is the Technology Impact Forecasting (TIF) technique, which generates an environment for the exploration and quantitative assessment of a technology's impact on a baseline system.

\section{METHODOLOGY}

\subsection{Overview}

The creation of a TIF analysis environment (Figure 3) in this paper follows the detailed methodology outlined in Soban and Mavris [56]. The TIF method includes sensitivities to design goals and constraints to evaluate the effect of a 'technology scenario'. Using the concept of multiplicative factors (known as $k$ factors) to model technologies by their effect on key metrics (e.g. vehicle mass), TIF can allow the assessment of existing and undefined technologies. Probabilistic analysis within the TIF environment then permits stakeholders to view not only what could happen, but how likely it is to happen [55]. TIF has previous applications in the aerospace field, but has not been used for analysing bus technologies. 
This paper addresses the challenge of synthesizing a compatible framework combining TIF and LCA approaches. However, consideration must first be given to the creation of a suitable life cycle model.

\subsection{Life Cycle Model Development}

\subsubsection{Model Overview}

The modelling environment contains multidisciplinary sub models integrated into the life cycle system boundary, consisting of materials processing and manufacturing (for vehicle and infrastructure), vehicle use, and fuel and electricity production phases (Figure 4). The following sections detail how the main multidisciplinary sub models are integrated into the life cycle system boundary. Under the guidance of ISO 14040 [26], comparisons between the two drivetrain technologies are made on the basis of the same function by including the boundary of other systems for battery electric vehicles, e.g. infrastructure requirements, battery replacements and electricity generation scenarios.

\subsubsection{Hybrid LCA Model}

The hybrid LCA model contains a bespoke EIO-LCA model (Box 1) for vehicle maintenance, manufacturing and infrastructure construction in the UK. Supply and use tables and GHG emissions datasets are UK specific [58,59]. Key calculated outputs of the EIO-LCA model are listed in Table 2.

Process-based LCA data inputs are used to calculate vehicle and battery production GHG emissions, $\mathrm{GHG}_{\text {manf }}$ (equation 3).

$G H G_{\text {manf }}=0.630\left(f_{c a p} C_{c a p}\right)+Q_{b a t t} G H G_{b a t t}$

where $f_{\text {cap }}$ is the multiplicative capital cost factor, $C_{\text {cap }}$ is the capital cost of the baseline vehicle (GBP), $Q_{\text {batt }}$ is the energy storage capacity $(\mathrm{kWh})$ and $\mathrm{GHG}_{\text {bat }}$ is the emissions from the production per $\mathrm{kWh}$ of the energy storage system $\left(\mathrm{kgCO}_{2} \mathrm{e} / \mathrm{kWh}\right)$. The vehicle acquisition cost, $\mathrm{C}_{\mathrm{acq}}$, is calculated using equation 4.

$C_{a c q}=f_{c a p} C_{c a p}+Q_{b a t t} C_{b a t t}$

where $C_{\text {batt }}$ is the energy storage cost per $\mathrm{kWh}$ of capacity (GBP/kWh).

The life cycle cost of infrastructure $\left(\mathrm{C}_{\mathrm{LC} \_ \text {infra }}\right)$, operation and maintenance costs $\left(\mathrm{C}_{\text {infra_main }}\right)$ and the respective GHG emissions ( $\mathrm{GHG}_{\text {infra, }} \mathrm{GHG}_{\text {infra_main }}$ ) are calculated using equations 5 and 6.

$C_{L C_{\text {infra }}}=C_{\text {infra }}+\sum_{y=0}^{Y_{S}}\left[\left(C_{\text {infra }} f_{o \& M}\right)(1+r)^{y}\right]$ 
$G H G_{L C_{\text {infra }}}=0.539 C_{\text {infra }}+\sum_{y=0}^{Y_{S}}\left[0.273\left(C_{\text {infra }} f_{\text {O\&M }}\right)\right]$

where $\mathrm{C}_{\text {infra }}$ is the capital infrastructure cost per bus, $\mathrm{y}$ is the service year (yr), $\mathrm{Y}_{\mathrm{s}}$ is the total number of service years (assumed 12 yrs [17]), $\mathrm{f}_{\mathrm{o} \& \mathrm{~m}}$ is the yearly infrastructure operation and maintenance cost as a percentage of the capital cost (3\% [49]) and $\mathrm{r}$ is the discount rate, 3.5\% [60]. Emissions coefficients derived from the EIO-LCA model (Table 2) are contained in equation 6.

\subsubsection{Use Phase Model}

An algorithm was developed for calculating the vehicle energy demand for the drive-cycle for both drivetrain configurations (Appendix A - Figure A1). Key assumptions and constants used are contained in the algorithm key (Appendix A). The BEB mass is calculated by subtracting the mass of a Euro VI engine (500 kg [61]), automatic transmission (329 kg [62]) and after-treatment systems (assumed 200 $\mathrm{kg}$ ) from the diesel tare mass and adding the mass of the motor-controller (350 $\mathrm{kg}[63])$, and the calculated battery mass. The total drive cycle energy demand, $\mathrm{W}_{\text {total }}(\mathrm{MJ})$, is calculated using equation 7 and the life cycle fuel or electricity cost in the use phase, $C_{\text {use }}$, is calculated using equation 8 .

$$
\begin{aligned}
& W_{\text {total }}=\left(\int_{t=0}^{t=n} W_{\text {trac }} d t / \eta_{\text {drive }}\right)+\int_{t=0}^{t=n} W_{\text {idle. }} d t+\left(P_{\text {aux }} / \eta_{\text {aux }}\right) \sum_{t=0}^{t=n} T-\left(\int_{t=0}^{t=n} W_{\text {regen }} . d t / \eta_{d r i v e}\right) \\
& C_{\text {use }}=\sum_{y=0}^{Y S}\left[\left(3.6 W_{\text {total }} C_{f / e} / \eta_{t h}\right)\left(D_{y} / D_{D C}\right)(1+r)^{y}\right]
\end{aligned}
$$

where $\eta_{\text {th }}$ is the engine thermal efficiency $(\%), \mathrm{C}_{\mathrm{f} / \mathrm{e}}$ is the fuel or electricity cost per $\mathrm{kWh}(\mathrm{GBP} / \mathrm{kWh})$, $D_{y}$ is the annual distance travelled (assumed 50,000 km) and $D_{D C}$ is the drive cycle distance covered. WTW fuel and electricity GHG emissions, GHGwTw, are calculated using equation 9.

$G H G_{W T W}=Y_{S}\left(D_{y} / D_{D C}\right)\left(W_{\text {total }} / \eta_{t h} \eta_{c h}\right)\left(G H G_{W T T}+G H G_{T T W}\right)$

where $\eta_{\mathrm{ch}}$ is the BEB charging efficiency, 97\% [64], $\mathrm{GHG}_{\mathrm{WTT}}$ is the WTT GHG emissions factor $\left(\mathrm{gCO}_{2} \mathrm{e} / \mathrm{MJ}\right)$ and $\mathrm{GHG}_{\mathrm{TTW}}$ is the TTW GHG emissions factor $\left(\mathrm{gCO}_{2} \mathrm{e} / \mathrm{MJ}\right)$ (Table 5). For the BEB configuration, $\eta_{\mathrm{th}}=100 \%$ in equations 8 and 9 . For the diesel configuration, $\eta_{\mathrm{ch}}=100 \%$ in equation 9 . Life cycle maintenance costs and GHG emissions account for the number of battery replacements required in the BEB's service life, calculated using equation 10 [5].

$B_{\text {life }}=N_{\text {cyc }} Q_{\text {batt }} / E_{k m} \rightarrow N_{\text {batt }}=Y_{s} D_{y} / B_{\text {life }} \quad$ where, $N_{\text {batt }} \in \mathrm{N}=\{1,2,3 \ldots N\}$

where $E_{k m}$ is the energy throughput per $\mathrm{km}(\mathrm{kWh} / \mathrm{km}), B_{\text {life }}$ is the energy storage life of the battery in terms of kilometres driven $(\mathrm{km})$ and $\mathrm{N}_{\text {batt }}$ is the number of replacements required throughout the service 
life of the BEB. Maintenance life cycle costs $\left(\mathrm{C}_{\mathrm{LC} \_ \text {main }}\right)$ and $\mathrm{GHG}$ emissions ( $\left.\mathrm{GHG}_{\mathrm{LC} \_ \text {main }}\right)$, are calculated using equations 11 and 12 respectively.

$C_{L C_{-} \text {main }}=\sum_{y=0}^{Y_{S}}\left[C_{\text {main }} D_{y}(1+r)^{y}\right]+N_{\text {batt }} C_{\text {batt }} Q_{\text {batt }}$

$\mathrm{GHG}_{\mathrm{LC} \_ \text {main }}=0.247\left(\mathrm{Y}_{\mathrm{s}} \mathrm{C}_{\text {main }} \mathrm{D}_{\mathrm{y}}\right)+N_{\text {batt }} C_{\text {batt }} Q_{\text {batt }}$

where $\mathrm{C}_{\text {main }}$ is the maintenance cost per $\mathrm{km}$, excluding battery replacements $(\mathrm{GBP} / \mathrm{km})$. The maintenance emissions coefficient derived from the EIO-LCA model (Box 1) is contained in equation 12.

\subsubsection{Life Cycle Model Outputs}

The total cost of ownership, $C_{T C O}$, and life cycle GHG emissions, $G H G_{L C}$, were calculated using equations 13 and 14 respectively.

$C_{T C O}=C_{a c q}+C_{L C_{-} \text {infra }}+C_{\text {use }}+C_{L C_{-} \text {main }}$

$G H G_{L C}=G H G_{\text {manf }}+G H G_{L C_{-} \text {infra }}+G H G_{W T W}+G H G_{L C_{-} \text {main }}$

\subsection{Creation of the TIF Environment}

\subsubsection{Baseline System}

The baseline system in this study was a conventional Euro VI double decker bus with an assumed tare mass of 11,000 kg, a passenger load of $2176 \mathrm{~kg}$ (32 passengers at $68 \mathrm{~kg}$ [65]) and a $4 \mathrm{~kW}$ auxiliary load. The London Urban Bus (LUB) drive-cycle, a $16.1 \mathrm{~km}$ real world test cycle incorporating rural and urban cycles [66], was used in all of the simulated scenarios.

\subsubsection{Selection of Candidate Technology Scenarios, Variables and Responses}

Three battery technologies suitable for road transportation application [67] were selected for assessment: lithium nickel-cobalt-manganese (NMC), lithium-iron phosphate (LFP) and lithiumtitanate (LTO) (Table 3). Unless otherwise stated, all BEBs were simulated with a $300 \mathrm{kWh}$ battery pack and assumed overnight depot charging. Two WTT electricity generation pathways were selected: the yearly average UK electricity supply mix (for 2016) and electricity generated solely from wind power. UK grid emissions are assumed to decrease proportionally with projected UK energy supply GHG emissions (calculated at 3.5\% per year from 2016 to 2028) [71]. Opportunity charging scenarios (assuming $300 \mathrm{~kW}$ fast charging infrastructure [72]) were simulated for the three battery pack technologies, downsized to $60 \mathrm{kWh}$. Finally, an additional $4 \mathrm{~kW}$ heating, ventilation and airconditioning (HVAC) unit was simulated for the diesel and LFP buses. 
$k$ _factors with both positive and negative effects on the baseline and the technology scenarios were identified from the review of previous models in literature (Table 4). As ICE and battery electric drivelines vary significantly in terms of upstream fuel and energy conversion processes and on-board propulsion energy conversions [75], the metrics selected for the TIF environment are variables in at least one technology scenario. The fuel and electricity costs used in applicable scenarios are shown in Table 5. Finally, the responses of interest were identified that quantify the whole life cycle impacts of the technologies to be assessed (bottom of Figure 4).

\subsubsection{Creation of Surrogate Models}

$k \_$factors were set as inputs into a design of experiments (DOE) table to assess the 'cause and effect' relationships between design variables and system responses. A central composite design was selected with one centre point, generating 159 computational runs. Performing variable combinations in the DOE table created response surface equations (RSEs), e.g. a polynomial equation representing the sensitivity of system inputs to outputs. The RSEs produce surrogate models of the entire system, capturing the empirical relationships and masking sensitive proprietary information. The RSEs were then mapped into an interactive visual profiler in the statistical analysis software package JMP ${ }^{8}$ [85]. This prediction profile formed the basis of the TIF environment (Figure 5).

\subsubsection{Probabilistic Analysis}

To account for uncertainty a shape distribution function (e.g. Gaussian, uniform, triangular, etc.) is assigned to each $k$ ffactor. The shape functions used for all scenarios and the rationale for selection of $k$ ffactor ranges are contained in Appendix B. An example of the shape distributions applied to each $k$ ffactor for the LFP BEB (UK grid) scenario is shown in Figure 6 . The shape functions were selected through consultation with industry practitioners and relevant literature (e.g. battery characteristics shown previously in Table 3). Monte Carlo simulation was conducted for 20,000 iterations and the results of each simulation run are presented as cumulative distribution functions (CDFs).

\section{RESULTS}

CDF plots of TCO and life cycle GHG emissions show both the likelihood and range of values that can occur for the LFP BEB (UK grid) scenario (Figure 7). The CDFs can be interpreted as the confidence of achieving a certain value, e.g. for a probability of 0.2 , the TCO response of the LFP (UK grid) is 95\% greater than the baseline conventional diesel result. Similarly, a probability of 0.8 corresponds to a 214\% TCO increase (a 119\% difference between the confidence levels). This result is interpreted as 'given the assumptions made in the probability distributions, there is an $80 \%$ confidence that the TCO of the LFP BEB scenario will be no greater than $214 \%$ compared to the diesel baseline'. The same 
probabilities for the life cycle GHG emissions plot yield $36 \%$ and $24 \%$ less emissions respectively. There is a $100 \%$ likelihood that life cycle GHG emissions are lower than the diesel baseline.

The baseline values for the conventional diesel Euro VI double decker bus are shown in Table 6 along with the $80 \%$ confidence response values for all eleven technology scenarios. This confidence has been selected as a reasonable risk level used by previous TIF studies $[55,56]$.

Despite a $38 \%$ to $41 \%$ decrease in energy costs, the TCO of the three battery scenarios operating from the UK grid is between $221 \%$ and $247 \%$ higher than the baseline (Table 6). This is primarily due to the high acquisition and battery replacement costs, with the LFP scenario remaining the cheapest option. WTW GHG emissions reductions of up to $65 \%$ are observed for all three battery scenarios due in part to the anticipated decrease in future UK energy supply emissions [71]. Even with increases in GHG emissions from the manufacture of the vehicle and infrastructure, life cycle emissions are up to $30 \%$ lower than the diesel baseline for the three battery scenarios. The LTO BEB scenario, despite having the most expensive battery pack and highest TCO, has the lowest additional cost increase per kg of GHG emissions mitigated. The high charge-discharge cycle life of LTO batteries, leading to fewer battery replacements, is the primary reason for this result.

The WTT wind electricity generation scenarios demonstrate a major advantage of BEBs: for every scenario, WTW GHG emissions are reduced by up to $97 \%$ compared to the baseline for the $80 \%$ confidence band (Table 6). A decrease in electricity cost per $\mathrm{kWh}$ for the wind-based scenarios yield significant energy cost reductions compared to the diesel baseline (up to 66\%) and noteworthy TCO reductions (from 13-19\%) compared to the UK grid-based BEB scenarios.

For the opportunity charging scenarios, the reduction in vehicle energy consumption is due to reduced battery capacity, resulting in a decrease in vehicle mass and up to a 47-49\% reduction in energy costs (Table 6). A smaller battery pack also yields cheaper acquisition costs for the BEB scenarios compared to the overnight charging scenarios. More frequent battery replacements are needed, but due to the lower pack cost, life cycle maintenance costs are lower than the overnight charging scenarios. Despite fast charging infrastructure costing approximately five times that of the overnight charging infrastructure, results show up to an additional 8-9\% TCO saving over the overnight charge scenarios. TCO is predicted to be over double that of the baseline diesel bus. Of all of the scenarios simulated, the opportunity charge LTO BEB yields the lowest additional cost increase per $\mathrm{kgCO}_{2} \mathrm{e}$ mitigated compared to the baseline diesel vehicle for the $80 \%$ probability band, aligning with previous research [49].

Results of the HVAC scenarios (Table 6) show that the more efficient drivetrain of the LFP BEB results in a 9\% energy cost increase with a HVAC unit compared to the LFP BEB operating on the UK grid. In comparison, the diesel vehicle with the HVAC unit has $19 \%$ higher energy costs than the baseline. 
The additional life cycle energy demand results in more battery replacements and higher maintenance costs and GHG emissions compared to the non-HVAC BEB. The LFP BEB (HVAC) has the highest TCO of all scenarios and still produces lower life cycle GHG emissions compared to the diesel baseline.

\section{DISCUSSION}

\subsection{Informing Decision Makers using the Life Cycle Framework}

By calculating both diesel and BEB impacts simultaneously, it can be inferred that the TIF environment can assess contrasting driveline technologies with relative ease, provided the $k$ factors included sufficiently cover the input requirements of all propulsion technologies evaluated. The results can be examined by decision makers to evaluate whether the technology has an acceptable risk level.

Comparison of the overnight and the opportunity charging scenarios reveals a trade-off between dependence on battery capacity and high-power charging infrastructure. Although the framework does not address the range implications of BEBs, these results do provide stakeholders with some answers to the complexities of designing and planning for the implementation of electric bus technologies. Given the current costs of charging infrastructure and battery packs, operators will find difficulties in justifying the purchase of BEBs purely from an economic perspective. By assigning additional resources to a technology and revisiting the assumptions in the shape distributions, the uncertainty bands would potentially decrease. The expected reduction in future battery pack costs could be one instance to revisit these scenarios with new assumptions [86]; increased mass-market production of lithium ion packs is expected to reduce battery acquisition costs, hence allowing for commercially viable BEBs.

Life cycle GHG emissions from BEBs are highly dependent on the electricity generation source, as demonstrated by the wind scenarios. BEBs in operation should be carefully selected and appraised with respect to emissions from electricity generation in the region of operation [17]. The life cycle framework first and foremost evaluates the impact of the vehicle itself, however it can be a powerful tool in assessing hypothetical or notional 'what-if?' electricity generation portfolios, as well as combinations of technology and operational conditions. The TIF environment is a powerful tool in realising what impact a conceptual design will have on whole life cycle costs and GHG emissions. Traditional TIF studies tend to evaluate technologies that are expected to benefit performance characteristics of a baseline. However, the HVAC scenarios demonstrate that the environment is also capable of assessing operational scenarios which have an adverse effect on vehicle performance.

\subsection{Assessing Risk and Uncertainty using the combined LCA-TIF Framework}

The novel LCA-TIF framework addresses some of the uncertainty and associated risks surrounding BEBs in terms of whole life cycle impacts via probabilistic analysis techniques, giving stakeholders confidence in the level of risk of a technology scenario. Users should be aware of the capabilities of the 
framework and the effect of shape function selection. Soban and Mavris [56] caution users of the TIF methodology: 'because the CDFs are entirely dependent on the shape distributions assigned and the technology scenarios defined, care needs to be taken that the shape functions are not inadvertently used to determine specific desired results'. The implication is that manipulating shape functions that are not representative of the technology could produce misleading life cycle results. Justifying shape function selection with additional data and consultation with disciplinary experts will ensure credible, traceable, and relevant technology assessments for stakeholders.

\subsection{Recommendations for Future Life Cycle Model Developments}

The life cycle model developed for this study may contribute to additional levels of uncertainty in the framework. For example, GHG emissions from the manufacturing and infrastructure phases rely heavily on the capital cost factors, an input to the EIO-LCA sub-model. Although EIO-LCA has been noted as a useful benchmarking tool for rapidly estimating life cycle emissions [21,40], identifying process improvements is difficult due to highly aggregated data. The use of process-based LCA data in bus life cycle studies is not new; previous research has used process-based LCA data for the manufacturing, maintenance and end-of-life phases of bus technologies [18,20,50,51,87]. However, the inclusion of additional process-based LCA data in the framework would help make more informed decisions and improve fidelity of the models used for the manufacturing, maintenance and end-of-life phases.

Life cycle impacts beyond the typical WTW or vehicle operation boundary can be distorted by the temporal scope and physical process pathways selected. This model, for example, does not include expected cost reductions of battery packs even though future pack replacements may be significantly cheaper and potentially have lower production emissions due to mass production [86]. Likewise, future energy costs remain static in the model, but including diesel or electricity cost prediction scenarios (e.g. [88]) would address this modelling gap. Some cost fluctuation can be accounted for by applying appropriate shape functions in the model and future BEB scenarios could address the cheaper overnight 'off peak' electricity tariffs and lower environmental impacts compared to 'peak' scenarios [48].

This model conducted a bus-to-bus comparison rather than a fleet-based approach, assuming that diesel and BEB technologies can complete the same route regardless of the range capabilities. However, Lajunen [5] found that additional BEBs are required for equivalent fleet operation, making the implementation of new fleets more expensive. Unique drive-cycles, auxiliary and passenger loads all affect the range and fleet size of plug-in vehicles. Therefore, a fleet-based approach would provide a more appropriate functional unit, as emissions reductions of a BEB fleet could potentially be less pronounced than vehicle-by-vehicle comparisons with diesel buses [89]. Fleet analysis would assist in the sizing and additional impact assessment of new infrastructure needs for plug-in vehicles. Finally, diesel and BEBs are not the only option available to operators; future model developments should appraise HEBs as 'stepping stones [7]' towards full electrification of urban bus transportation. 


\section{CONCLUSIONS}

Meta-analysis of cost and GHG emissions from literature demonstrates high levels of variation and potential uncertainty when comparing life cycle impacts of bus technologies and operational conditions. This paper outlines the development of a novel framework combining TIF and LCA approaches to assist decision makers in addressing the uncertainty surrounding the life cycle impacts of the manufacture, use, maintenance and infrastructure of diesel and BEB technologies. The framework is realised as a rapid assessment environment capable of stochastic simulation to quantify this potential uncertainty. The framework evaluates positive and negative impacts of a bus technology and its response to "whatif?' operational scenarios. The framework enables stakeholders to make technology adoption and resource allocation decisions based on the risk of a scenario and provides a level of confidence in a technologies' ability to mitigate whole life cycle impacts. The main findings and lessons learned from the development and use of this framework are as follows:

- For every battery electric bus scenario, there is an $80 \%$ confidence that life cycle GHG emissions are mitigated by $10 \%$ to $58 \%$ compared to the baseline diesel bus, but life cycle costs are $129 \%$ to $247 \%$ higher.

- An opportunity charged LTO BEB is the most cost-effective scenario for mitigating GHG emissions per additional increase in cost to the operator. Stakeholders may wish to pursue this promising technology by assigning additional resources and revisiting assumptions made in the framework.

- A trade-off between dependence on battery capacity and high-power charging infrastructure is apparent between overnight and opportunity charging scenarios. The evaluation of a narrow system boundary (i.e. a WTW assessment) would overlook these key interactions in the life cycle.

- A hybrid-LCA approach provides a useful first insight into the direct and indirect impacts of alternative bus technologies. However, additional process-based modelling of manufacturing, maintenance and end-of-life phases would facilitate more informed early stage design decisions.

- Temporal aspects of the framework are limited; future model iterations should account for uncertainty scenarios of future energy mix pathways and component cost variations.

- The evaluation of a fleet-by-fleet assessment would offer a more appropriate functional unit and address the range limitations of BEBs. Additional drivetrain technologies should be integrated into the framework to enable side-by-side comparisons with conventional diesel buses.

\section{ACKNOWLEDGEMENTS}

The authors would like to thank the Northern Ireland Department for the Economy and Wrights Group Ltd for funding the research and the two anonymous reviewers for the insightful comments and feedback. The authors would also like to acknowledge the continued support from members of the William Wright Technology Centre (W-Tech) at Queen's University Belfast. 


\section{SUPPORTING INFORMATION}

Supplementary data associated with this article can be found in the online version at doi:10.1016/j.rser.2018.08.045.

\section{APPENDIX A}

The algorithm for calculating drive cycle energy consumption is shown in Figure A.1, where $\mathrm{i}=$ current time step $(-), \mathrm{t}=$ time $(\mathrm{s}), \mathrm{T}=$ difference between timesteps $(\mathrm{s}), \mathrm{D}=$ distance $(\mathrm{m}), \mathrm{v}=$ vehicle velocity $(\mathrm{m} / \mathrm{s}), \mathrm{a}=$ vehicle acceleration $\left(\mathrm{m} / \mathrm{s}^{2}\right), \alpha=\operatorname{road}$ gradient $(\mathrm{rad}), \mathrm{e}=$ elevation $(\mathrm{m}), \mathrm{F}_{\text {trac }}=$ vehicle tractive force $(N), F_{\text {aero }}=$ vehicle aerodynamic drag force $(N), F_{r r}=$ vehicle rolling resistance force $(N), F_{c r}=$ vehicle climbing resistance force $(\mathrm{N}), \mathrm{m}=$ vehicle mass $(\mathrm{kg}), \rho_{\text {air }}=$ density of air, $1.225 \mathrm{~kg} / \mathrm{m}^{3}, \mathrm{C}_{\mathrm{d}}=$ drag coefficient $(-), A_{f}=$ vehicle frontal area $\left(\mathrm{m}^{2}\right), g=$ acceleration due to gravity, $9.81 \mathrm{~m} / \mathrm{s}^{2}, C_{r r}=$ coefficient of rolling resistance $(-), \mathrm{P}_{\text {brake }}=$ braking power $(\mathrm{kW}), \mathrm{W}_{\text {brake }}=$ braking energy $(\mathrm{MJ}), \mathrm{P}_{\text {trac }}=$ tractive power $(\mathrm{kW}), \mathrm{W}_{\text {trac }}=$ tractive energy $(\mathrm{MJ}), \mathrm{v}_{\text {low }}=$ lower velocity bound for regeneration, $5 \mathrm{~km} / \mathrm{s}$ [64], $a_{\max }=$ maximum deceleration bound for regeneration, $-3 \mathrm{~m} / \mathrm{s}^{2}$ [64], $\mathrm{W}_{\text {regen }}=$ braking energy regenerated $(\mathrm{MJ}), \mathrm{W}_{\text {idle }}=$ idling energy $(\mathrm{MJ}), \mathrm{CV}=$ calorific value of diesel fuel, $42.92 \mathrm{MJ} / \mathrm{kg}$ [78], $\mathrm{FC}_{\text {idle }}=$ idle fuel consumption rate $(\mathrm{L} / \mathrm{h}), \rho_{\text {fuel }}=$ density of fuel, $0.839 \mathrm{~kg} / \mathrm{L}[78], \mathrm{W}_{\text {total }}=$ total energy demand for drive cycle (MJ), $\eta_{\text {drive }}=$ drivetrain efficiency, $\eta_{\text {aux }}=$ auxiliary system conversion efficiency $(\%), \mathrm{P}_{\mathrm{aux}}=$ auxiliary electrical power demand $(\mathrm{kW})$ and $\eta_{\text {regen }}=$ regeneration system efficiency $(\%)$.

\section{APPENDIX B}

Shape functions used in each technology scenario are shown in Table B.1. Dashes in Table B.1 indicate that the input has been left at the baseline value.

\section{REFERENCES}

[1] UNFCCC. Report of the Conference of the Parties on its twenty-first session, held in Paris from 30 November to 13 December 2015. Addendum-Part Two: Action Taken by the Conference of the Parties 2015;01194:1-36.

[2] European Commission. COMMUNICATION FROM THE COMMISION: A Roadmap for moving to a competitive low carbon economy in 2050. COM/2011/0112 2011;34:1-34. doi:10.1002/jsc.572.

[3] European Commission. The EU explained: Transport. Brussels: 2014. doi:10.2775/13082.

[4] European Parliament. Regulation (EC) No 595/2009 on type-approval of motor vehicles and engines with respect to emissions from heavy duty vehicles (Euro VI) and on access to vehicle repair and maintenance information and amending Regulation (EC) No 715/2007 and Directive 2007. Official Journal of the European Union 2009;52.

[5] Lajunen A. Energy consumption and cost-benefit analysis of hybrid and electric city buses. Transportation Research Part C: Emerging Technologies 2014;38:1-15. doi:10.1016/j.trc.2013.10.008.

[6] Lajunen A, Lipman T. Lifecycle cost assessment and carbon dioxide emissions of diesel, natural 
gas, hybrid electric, fuel cell hybrid and electric transit buses. Energy 2016;106:329-42. doi:10.1016/j.energy.2016.03.075.

[7] Mahmoud M, Garnett R, Ferguson M, Kanaroglou P. Electric buses: A review of alternative powertrains. Renewable and Sustainable Energy Reviews 2016;62:673-84. doi:10.1016/j.rser.2016.05.019.

[8] Ally J, Pryor T. Life cycle costing of diesel, natural gas, hybrid and hydrogen fuel cell bus systems: An Australian case study. Energy Policy 2016;94. doi:10.1016/j.enpol.2016.03.039.

[9] Ercan T, Tatari O. A hybrid life cycle assessment of public transportation buses with alternative fuel options. International Journal of Life Cycle Assessment 2015;20:1213-31. doi:10.1007/s11367-015-0927-2.

[10] Ercan, Zhao Y, Tatari O, Pazour JA. Optimization of transit bus fleet's life cycle assessment impacts with alternative fuel options. Energy 2015;93:323-34. doi:10.1016/j.energy.2015.09.018.

[11] Ribau JP, Silva CM, Sousa JMC. Efficiency, cost and life cycle CO2 optimization of fuel cell hybrid and plug-in hybrid urban buses. Applied Energy 2014;129:320-35. doi:10.1016/j.apenergy.2014.05.015.

[12] Simon B, Tamaska L, Kovats N. Analysis of Global and Local Environmental Impacts of Bus Transport by LCA Methodologies. Hungarian Journal of Industrial Chemistry 2010;38:155-8.

[13] Wang R, Wu Y, Ke W, Zhang S, Zhou B, Hao J. Can propulsion and fuel diversity for the bus fleet achieve the win-win strategy of energy conservation and environmental protection? Applied Energy 2015;147:92-103. doi:10.1016/j.apenergy.2015.01.107.

[14] Xu Y, Gbologah FE, Lee DY, Liu H, Rodgers MO, Guensler RL. Assessment of alternative fuel and powertrain transit bus options using real-world operations data: Life-cycle fuel and emissions modeling. Applied Energy 2015;154:143-59. doi:10.1016/j.apenergy.2015.04.112.

[15] Zhou B, Wu Y, Zhou B, Wang R, Ke W, Zhang S, et al. Real-world performance of battery electric buses and their life-cycle benefits with respect to energy consumption and carbon dioxide emissions. Energy 2016;96:603-13. doi:10.1016/j.energy.2015.12.041.

[16] Chan S, Miranda-Moreno LF, Alam A, Hatzopoulou M. Assessing the impact of bus technology on greenhouse gas emissions along a major corridor: A lifecycle analysis. Transportation Research Part D: Transport and Environment 2013;20. doi:10.1016/j.trd.2013.01.004.

[17] Cooney G, Hawkins TR, Marriott J. Life cycle assessment of diesel and electric public transportation buses. Journal of Industrial Ecology 2013;17. doi:10.1111/jiec.12024.

[18] García Sánchez JA, López Martínez JM, Lumbreras Martín J, Flores Holgado MN. Comparison of Life Cycle energy consumption and GHG emissions of natural gas, biodiesel and diesel buses of the Madrid transportation system. Energy 2012;47:174-98. doi:10.1016/j.energy.2012.09.052.

[19] Hao H, Wang H, Song L, Li X, Ouyang M. Energy consumption and GHG emissions of GTL fuel by LCA: Results from eight demonstration transit buses in Beijing. Applied Energy 2010;87. doi:10.1016/j.apenergy.2010.03.029.

[20] Lin X, Lü B, Tian L, Liu J, Yang J. Analysis of energy conservation and greenhouse gas emissions reduction potential of buses in Beijing city based on life cycle assessment [article in Chinese]. Huanjing Kexue Xuebao/Acta Scientiae Circumstantiae 2015;35. doi:10.13671/j.hjkxxb.2014.0872.

[21] Croft-McKenzie E, Durango-Cohen PL. Environmental life-cycle assessment of transit buses with alternative fuel technology. Transportation Research Part D: Transport and Environment 2012;17:39-47. doi:10.1016/j.trd.2011.09.008.

[22] M.J. Bradley \& Associates L. Comparison of Modern CNG, Diesel and Diesel Hybrid-Electric Transit Buses. Concord, MA - Washington DC: 2013.

[23] Ou X, Zhang X, Chang S. Alternative fuel buses currently in use in China: Life-cycle fossil energy use, GHG emissions and policy recommendations. Energy Policy 2010;38:406-18. doi:10.1016/j.enpol.2009.09.031.

[24] Chen R, Wang N, Ma J. Life cycle cost analysis of the Fuel Cell Bus based on Chinese bus cycle. Advanced Materials Research 2012;403-408:3220-3. doi:10.4028/www.scientific.net/AMR.403-408.3220.

[25] Wang N, Gong Z, Ma J. Hybrid Electric and Battery Electric City Buses Benefit Analysis Based 
on Lifecycle Cost and Emission. Advanced Materials Research 2012;347-353:952-5. doi:10.4028/www.scientific.net/AMR.347-353.952.

[26] International Organisation for Standardization. BS EN ISO 14040:2006 Environmental Management - Life Cycle Assessment - Principles and Framework. International Organisation for Standardization 2006;14040.

[27] International Organisation for Standardization. BS EN ISO 14044:2006 Environmental Management - Life Cycle Assessment - Requirements and Guidelines. International Organisation for Standardization 2006;14044.

[28] Moro A, Helmers E. A new hybrid method for reducing the gap between WTW and LCA in the carbon footprint assessment of electric vehicles. International Journal of Life Cycle Assessment 2017;22:4-14. doi:10.1007/s11367-015-0954-z.

[29] MacLean HL, Lave LB. Evaluating automobile fuel/propulsions system technologies. Progress in Energy and Combustion Science 2003;29:1-69. doi:10.1016/S0360-1285(02)00032-1.

[30] Gruosso G. An Approach for Vehicle Electrification. IEEE Transport Electrification Community Newsletter 2015.

[31] Bae C, Kim J. Alternative fuels for internal combustion engines. Proceedings of the Combustion Institute 2017;36:3389-413. doi:10.1016/j.proci.2016.09.009.

[32] Barbosa FC. Pure Electric Bus Traction Technology Overview - A Path Towards Enhanced Environmental Performance and Efficiency for Transit Bus Fleets 2014-36-0205 E. SAE Technical Paper 2014.

[33] Hannan MA, Azidin FA, Mohamed A. Hybrid electric vehicles and their challenges: A review. Renewable and Sustainable Energy Reviews 2014;29:135-50. doi:10.1016/j.rser.2013.08.097.

[34] Poullikkas A. Sustainable options for electric vehicle technologies. Renewable and Sustainable Energy Reviews 2015;41:1277-87. doi:10.1016/j.rser.2014.09.016.

[35] Yong JY, Ramachandaramurthy VK, Tan KM, Mithulananthan N. A review on the state-of-theart technologies of electric vehicle, its impacts and prospects. Renewable and Sustainable Energy Reviews 2015;49:365-85. doi:10.1016/j.rser.2015.04.130.

[36] Knight FH. Risk, Uncertainty and Profit. Boston, MA: Hart, Schaffner \& Marx; Houghton Mifflin Co.; 1921. doi:10.1017/CBO9780511817410.005.

[37] Hubbard DW. How to Measure Anything: Finding the Value of "Intangibles" in Business. Hoboken, NJ: John Wiley \& Sons Ltd; 2007.

[38] Lenzen M. Errors in Conventional and Input-Output - based Life-Cycle Inventories. Journal of Industrial Ecology 2001;4:127-48. doi:10.1162/10881980052541981.

[39] Hendrickson CT, Lave LB, Matthews HS. Environmental Life Cycle Assessment of Goods and Services: An Input-Output Approach. 1st ed. Washington DC: Resources for the Future; 2006.

[40] Michalek JJ, Hendrickson CT, Cagan J. Using Economic Input-Output Life Cycle Assesment to Guide Sustainable Design. Proceedings of the 2011 International Design Engineering Technical Conferences and Computers and Information in Engineering Conference IDETC/CIE 2011 August 28-31, 2011, Washington, DC, USA, Washington, DC: ASME; 2011, p. 1-8.

[41] Matthews HS, Hendrickson CT, Matthews DH. Advanced Life Cycle Models (Chapter 9). Life Cycle Assessment: Quantitative Approaches for Decisions That Matter, lcatextbook.com; 2015.

[42] Durango-Cohen PL, McKenzie EC. Trading off costs, environmental impact, and levels of service in the optimal design of transit bus fleets. Transportation Research Procedia 2017;23:1020-32. doi:10.1016/j.trpro.2017.05.056.

[43] Argonne National Laboratory. GREET® The Greenhouse gases, Regulated Emissions, and Energy use in Transportation Model 2017. https://greet.es.anl.gov/index.php (accessed March 9, 2017).

[44] Argonne National Laboratory. Alternative Fuel Life-Cycle Environmental and Economic Transportation (AFLEET) Tool 2017. https://greet.es.anl.gov/afleet_tool (accessed March 9, 2017).

[45] Das HS, Tan CW, Yatim AHM. Fuel cell hybrid electric vehicles: A review on power conditioning units and topologies. Renewable and Sustainable Energy Reviews 2017;76:26891. doi:10.1016/j.rser.2017.03.056.

[46] Ribau JP, Sousa JMC, Silva CM. Reducing the carbon footprint of urban bus fleets using multiobjective optimization. Energy 2015;93. doi:10.1016/j.energy.2015.09.112. 
[47] Yang D, Liu L, Zeng C, Han L. Life cycle analysis on energy efficiency and CO2 emissions of China's new energy city bus. Advanced Materials Research 2012;512-515:2598-602. doi:10.4028/www.scientific.net/AMR.512-515.2598.

[48] Foley A, Tyther B, Calnan P, Ó Gallachóir B. Impacts of Electric Vehicle charging under electricity market operations. Applied Energy 2013;101:93-102. doi:10.1016/j.apenergy.2012.06.052.

[49] Lajunen A. Lifecycle costs and charging requirements of electric buses with different charging methods. Journal of Cleaner Production 2018;172:56-67. doi:10.1016/j.jclepro.2017.10.066.

[50] Ally J, Pryor T. Life-cycle assessment of diesel, natural gas and hydrogen fuel cell bus transportation systems. Journal of Power Sources 2007;170. doi:10.1016/j.jpowsour.2007.04.036.

[51] García Sánchez JA, López Martínez JM, Lumbreras Martín J, Flores Holgado MN, Aguilar Morales H. Impact of Spanish electricity mix, over the period 2008-2030, on the Life Cycle energy consumption and GHG emissions of Electric, Hybrid Diesel-Electric, Fuel Cell Hybrid and Diesel Bus of the Madrid Transportation System. Energy Conversion and Management 2013;74:332-43. doi:10.1016/j.enconman.2013.05.023.

[52] Nordelöf A, Messagie M, Tillman AM, Ljunggren Söderman M, Van Mierlo J. Environmental impacts of hybrid, plug-in hybrid, and battery electric vehicles - what can we learn from life cycle assessment? International Journal of Life Cycle Assessment 2014;19:1866-90. doi:10.1007/s11367-014-0788-0.

[53] Raychaudhuri S. Introduction to Monte Carlo Simulation. Simulation Conference, 2008 WSC 2008 2008:91-100. doi:10.1109/WSC.2008.4736059.

[54] McCleese DL, LaPuma PT. Using monte carlo simulation in life cycle assessment for electric and internal combustion vehicles. The International Journal of Life Cycle Assessment 2002;7:230-6. doi:10.1007/BF02978878.

[55] Soban DS, Zeune C. Technology assessment for a complex aircraft system using technology scenarios. The Journal of Defense Modeling and Simulation: Applications, Methodology, Technology 2014. doi:10.1177/1548512914540230.

[56] Soban DS, Mavris DN. Assessing the Impact of Technology on Aircraft Systems Using Technology Impact Forecasting. Journal of Aircraft 2013;50:1380-93. doi:10.2514/1.C031871.

[57] Carnegie Mellon University Green Design Institute. Economic input-output life cycle assessment (EIO-LCA). US 2002 Benchmark Model - producer price 2010. www.eiolca.net (accessed February 27, 2017).

[58] Office for National Statistics. Dataset: Input-output supply and use table (2014) 2016. https://www.ons.gov.uk/economy/nationalaccounts/supplyandusetables/datasets/inputoutputsu pplyandusetables (accessed June 5, 2017).

[59] Office for National Statistics. Dataset: Atmospheric Emissions/Greenhouse Gas Emissions/By Economic Sector and Gas, United Kingdom (2014) 2017. https://www.ons.gov.uk/economy/environmentalaccounts/datasets/ukenvironmentalaccountsat mosphericemissionsgreenhousegasemissionsbyeconomicsectorandgasunitedkingdom (accessed June 5, 2017).

[60] HM Treasury. The Green Book: Appraisal and Evaluation in Central Government. Evaluation 2011:118. doi:http://greenbook.treasury.gov.uk/index.htm.

[61] Daimler AG. The new engines: BlueEfficiency Power units in Euro VI for a wide range of applications. 2018.

[62] Voith Turbo GmbH. Combining Ride Comfort with Economy DIWA.5. Heidenheim, Germany: 2017.

[63] Siemens. ELFA Components Data Sheets (Siemens PEM Motor 1DB2016). 2011.

[64] Gao Z, Lin Z, LaClair TJ, Liu C, Li JM, Birky AK, et al. Battery capacity and recharging needs for electric buses in city transit service. Energy 2017;122:588-600. doi:10.1016/j.energy.2017.01.101.

[65] LowCVP. Low Emission Bus Testing Guidance for test houses. 2015.

[66] LowCVP. Low Emission Bus Testing and Accredidation Procedures n.d. http://www.lowcvp.org.uk/Hubs/leb/TestingandAccreditation/TestingAccreditationProcedures. htm. 
[67] Tie SF, Tan CW. A review of energy sources and energy management system in electric vehicles. Renewable and Sustainable Energy Reviews 2013;20:82-102. doi:10.1016/j.rser.2012.11.077.

[68] Ambrose H, Kendall A. Effects of battery chemistry and performance on the life cycle greenhouse gas intensity of electric mobility. Transportation Research Part D: Transport and Environment 2016;47:182-94. doi:10.1016/j.trd.2016.05.009.

[69] California Air Resources Board. Advanced Clean Transit Battery Cost for Heavy-Duty Electric Vehicles. 2016.

[70] Jungmeier G. IEA HEV Task 33 “ Battery Electric Buses ” Battery Electric Buses Project International Energy Agency - Hybrid and Electric Vehicles Technology Collaboration Programme. International Conference on Electric Mobility and Public Transport, Santiago, Chile: 2017.

[71] Department for Business Energy \& Industrial Strategy. Updated energy and emissions projections: 2017 Annex A (Reference Scenario). London: 2018.

[72] Kunith A, Mendelevitch R, Goehlich D. Electrification of a city bus network - An optimization model for cost-effective placing of charging infrastructure and battery sizing of fast charging electric bus systems. International Journal of Sustainable Transport 2017;11:707-20. doi:10.1080/15568318.2017.1310962.

[73] Robert Bosch GmbH. Bosch Automotive Handbook. 9th ed. John Wiley \& Sons Ltd; 2014.

[74] Advanced Clean Transit. Advanced Clean Transit - Cost Assumptions and Data Sources 2016. https://www.arb.ca.gov/msprog/bus/tco_assumptions.xlsx (accessed April 2, 2018).

[75] Guzzella L, Sciarretta A. Vehicle Propulsion Systems Introduction to Modeling and Optimization. 3rd ed. Springer-Verlag Berlin Heidelberg; 2013. doi:10.1007/978-3-642-359132.

[76] Edwards R, Hass H, Larivé J-F, Lonza L, Mass H, Rickeard D. WELL-TO-WHEELS Report Version 4.a JEC WELL-TO-WHEELS ANALYSIS WELL-TO-WHEELS ANALYSIS OF FUTURE AUTOMOTIVE FUELS AND POWERTRAINS IN THE EUROPEAN CONTEXT. 2014. doi:10.2790/95533.

[77] MyGridGB, Portal E. MyGridGB Historical Data - Electricity since 20122018. http://www.mygridgb.co.uk/historicaldata/ (accessed April 9, 2018).

[78] Department for Business Energy \& Industrial Strategy. Greenhouse gas reporting: conversion factors 2017. Conversion Factors 2017 - Full Set (for Advanced Users) 2017. https://www.gov.uk/government/publications/greenhouse-gas-reporting-conversion-factors2017 (accessed May 24, 2018).

[79] Schlomer S, Bruckner T, Fulton L, Hertwich E, McKinnon A, Perczyk D, et al. Annex III: Technology-Specific Cost and Performance Parameters. Climate Change 2014: Mitigation of Climate Change Contribution of Working Group III to the Fifth Assessment Report of the Intergovernmental Panel on Climate Change 2014:1329-56. doi:http://report.mitigation2014.org/report/ipcc_wg3_ar5_annex-ii.pdf.

[80] LowCVP. LEB Certificate - Wrightbus Streedeck. 2016.

[81] Department for Business Energy and Industrial Strategy. Weekly road fuel prices statistical dataset (2016). 2016.

[82] UK Department for Transport. Bus Service Operators Grant rates. 2014.

[83] Department for Business Energy \& Industrial Strategy. Gas and electricity prices in the nondomestic sector. 2018.

[84] Department for Business Energy \& Industrial Strategy. Electricity Generation Costs. 2016.

[85] JMP®, Version 12.1. SAS Institute Inc., Cary, NC, 1989-2007 n.d.

[86] Nykvist B, Nilsson M. Rapidly falling costs of battery packs for electric vehicles. Nature Climate Change 2015;5:329.

[87] Ally J. Life Cycle Assessment and Life Cycle Costing of Hydrogen Fuel Cell, Natural Gas, and Diesel Bus Transportation Systems in Western Australia [PhD Thesis]. Murdoch University, Perth, Western Australia, 2015.

[88] Department for Business Energy \& Industrial. Updated energy and emissions projections: 2017 - Annex M: Growth assumptions and prices. 2018.

[89] Meinrenken CJ, Lackner KS. Fleet view of electrified transportation reveals smaller potential to 
reduce GHG emissions. Applied Energy 2015;138. doi:10.1016/j.apenergy.2014.10.082.

[90] Eudy L, Jeffers M, Eudy L, Jeffers M. Foothill Transit Battery Electric Bus Demonstration Results : Second Report Foothill Transit Battery Electric Bus Demonstration Results : Second Report. 2017. 


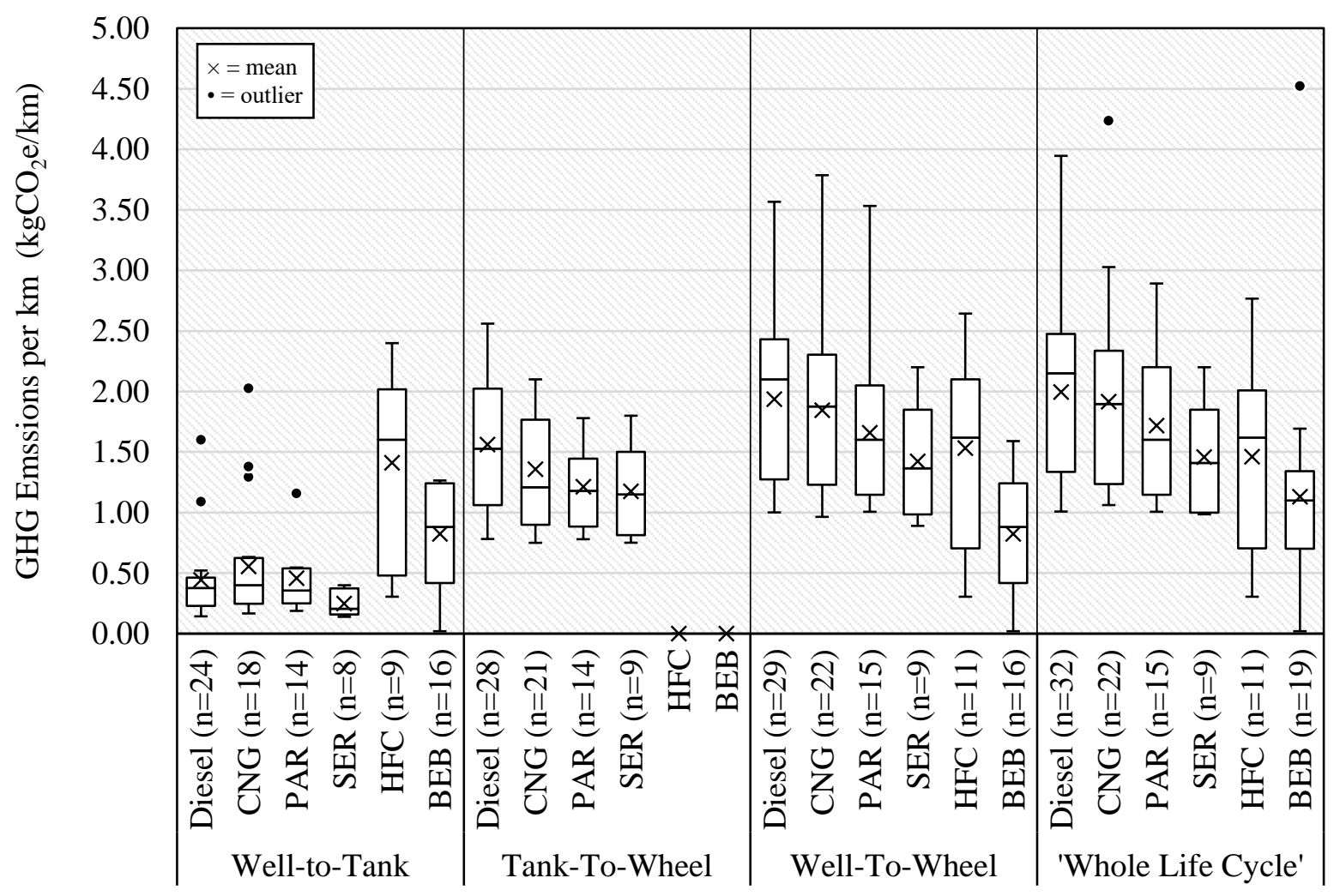

Figure 1. Box and whisker plots of GHG emissions of key life cycle phases for 6 of the most common drivetrain technologies evaluated in literature: diesel, compressed natural gas $(C N G)$, parallel hybrid (PAR), series hybrid (SER), hydrogen fuel cell (HFC) and a battery electric bus (BEB) technologies. Sources: [7,9,11-23] converted to a functional unit of 1 vehicle-km. 'Whole Life Cycle' refers to the entire system boundary considered by each cited source. Table 1 provides descriptions of the Well-toTank, Tank-to-Wheel and Well-to-Wheel terms. See supplementary material for data. 


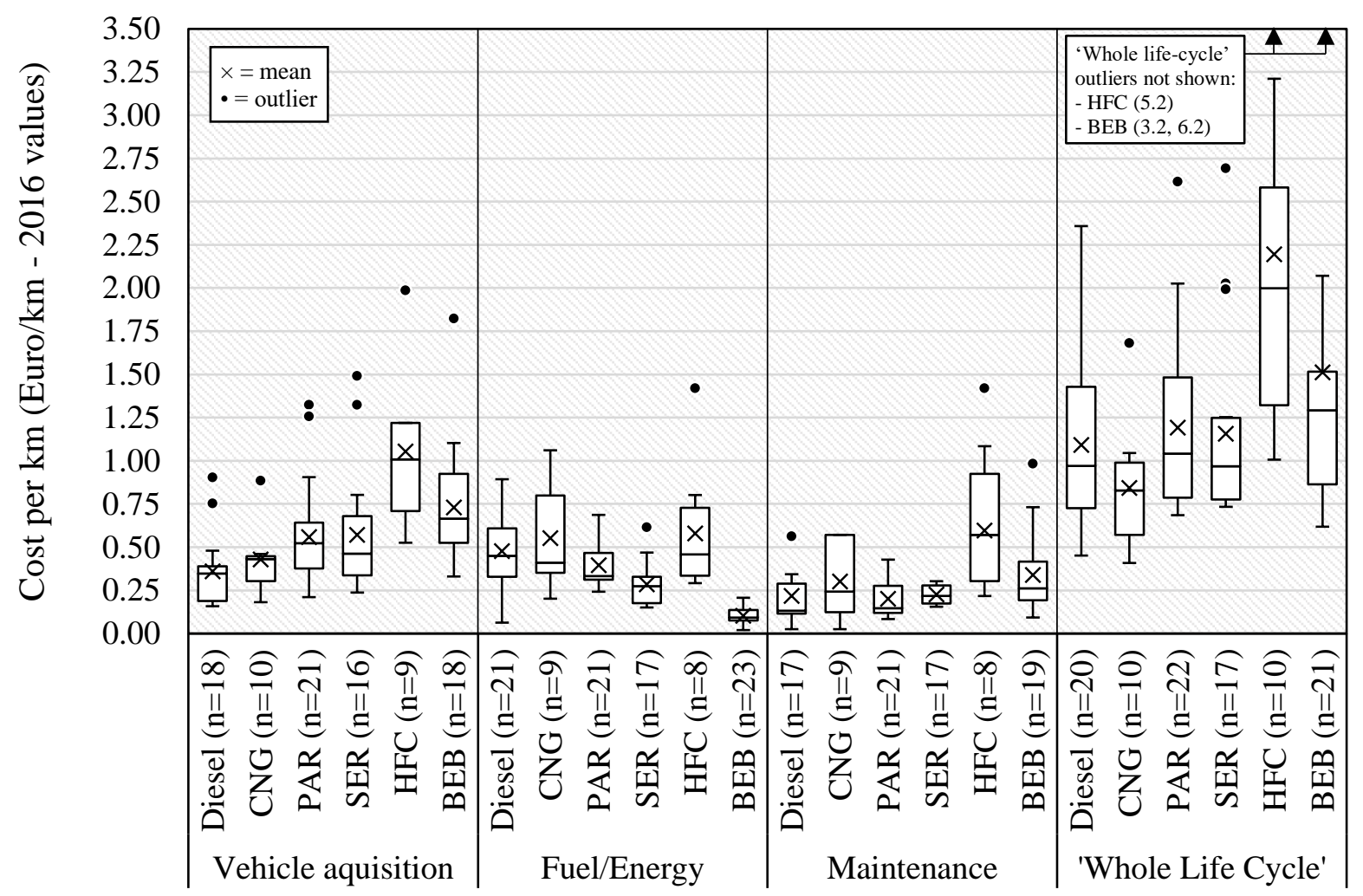

Figure 2. Box and whisker plots of costs (converted to 2016 equivalent values) of key life cycle phases for 6 of the most common drivetrain technologies evaluated in literature: diesel, compressed natural gas (CNG), parallel hybrid (PAR), series hybrid (SER), hydrogen fuel cell (HFC) and a battery electric bus (BEB) technologies. Sources: [5-9,15,21,24,25]. 'Whole Life Cycle' refers to the entire system boundary considered by each cited source. Table 1 provides descriptions of the Well-to-Tank, Tank-to-Wheel and Well-to-Wheel terms. See supplementary material for data. 


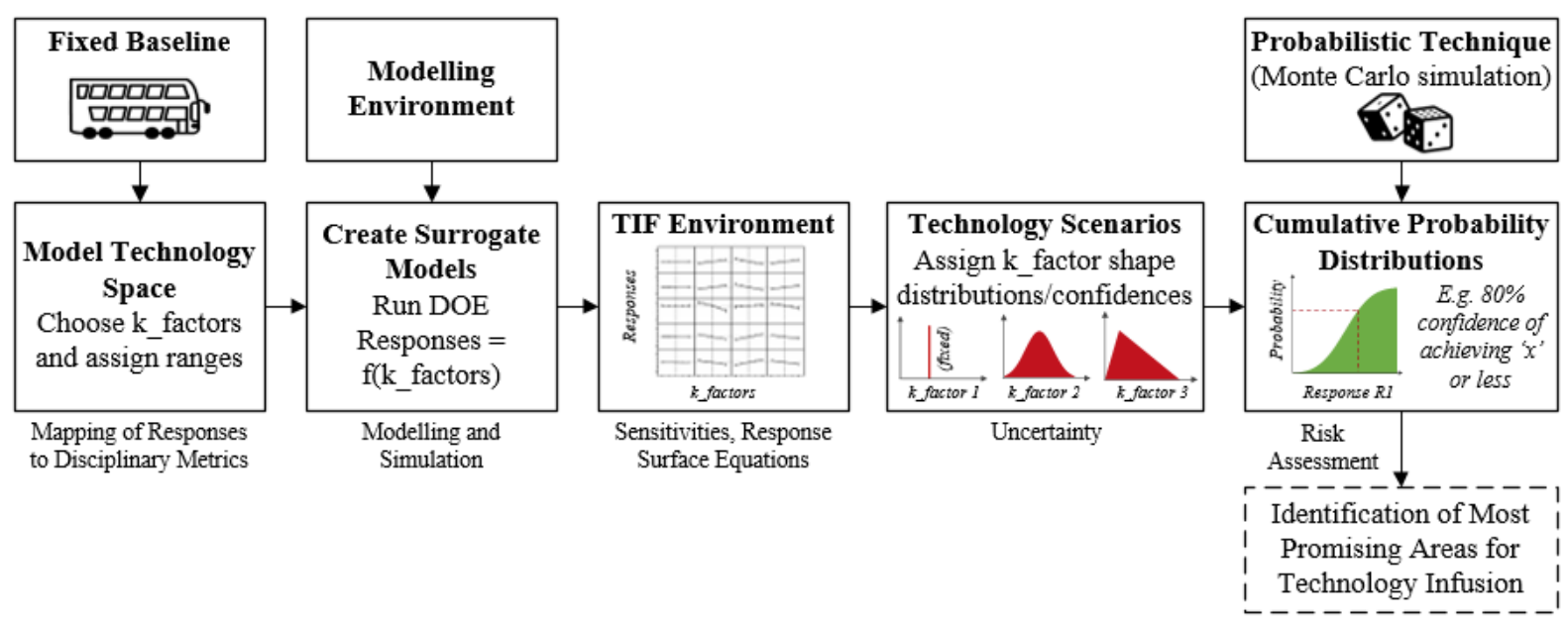

Figure 3. Process of creating a Technology Impact Forecasting analysis environment for assessing technology scenarios. Adapted from [55,56]. 


\section{Model inputs}

Note: refer to Table 4 for ranges of $k \_$factors.

Operational Characteristics

- Drive cycle = LUB

- Annual distance per year $=50,000 \mathrm{~km}$

- Years in service $=12$ years

- Average passenger mass $=68 \mathrm{~kg}$

- Average number of passengers $=32$

General Vehicle Properties

- Unladen mass $=k$ factor

- Frontal area $=10 . \overline{2} \mathrm{~m}^{2}$

- Drag coefficient $=0.65$ (-)

- Coefficient of rolling resistance $=0.01(-)$

- Constant auxiliary power $=k$ _factor

- Auxiliary system efficiency $=k$ factor

\section{Infrastructure}

- Capital infrastructure cost $=k \_$factor

- Infrastructure operation and maintenance

cost per year, as a percentage of

annualised capital investment $=3 \%$
Diesel Drivetrain Properties

- Thermal efficiency $=40 \%$

- Idle fuel consumption $=0.9 \mathrm{~L} / \mathrm{hr}$

- Drivetrain efficiency $=k$ factor

- Engine mass $=500 \mathrm{~kg}$

- Transmission mass $=329 \mathrm{~kg}$

- Aftertreatment mass $=200 \mathrm{~kg}$

- Fuel calorific value $=42.9 \mathrm{MJ} / \mathrm{kg}$

- Fuel density = $838.93 \mathrm{~kg} / \mathrm{m}^{3}$

Economics

- Capital cost of diesel bus = 190,000 GBP

- BEB capital cost factor (excluding

battery pack) $=k$ factor

- Battery pack cost per $\mathrm{kWh}=k \_$factor

- Maintenance cost per $\mathrm{km}=k \_$factor

- Energy cost $=k \_$factor

- Discount rate $=3.5 \%$
BEB Drivetrain Properties

- Drivetrain efficiency $=k \_$factor

- Charging efficiency $=97 \%$

- Maximum vehicle acceleration bound for regenerative braking $=-3 \mathrm{~m} / \mathrm{s}^{2}$

- Lower vehicle velocity bound for regenerative braking $=5 \mathrm{~m} / \mathrm{s}$

- Motor-controller mass $=350 \mathrm{~kg}$

- Battery energy density $=k \_$factor

- Battery capacity $=k \_$factor

- Battery cycles $=k \_$factor

- Battery pack production emissions per

$\mathrm{kWh}$ capacity $=k$ ffactor

Emissions Coefficients

- WTT GHG emissions per MJ = $k$ factor

- TTW emissions per MJ = $k$ _factor

- Average annual electricity grid emissions reduction per year $=3.5 \%$

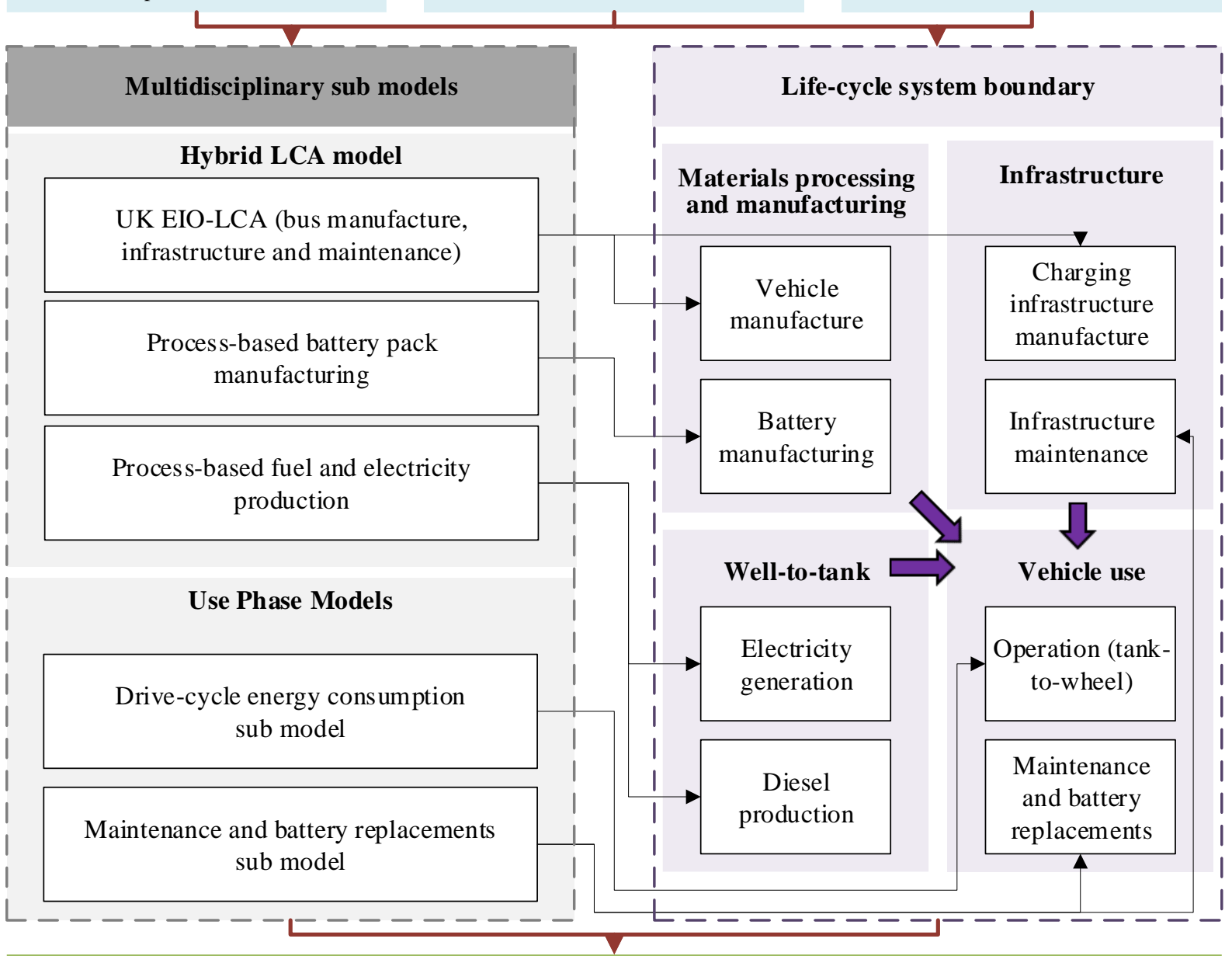

\section{Model outputs}

\section{Costs (GBP)}

- Vehicle acquisition cost

Energy cost (diesel fuel or electricity)

- Maintenance cost (including battery replacements)

Infrastructure cost (including maintenance of infrastructure)

Total cost of ownership (TCO)

\section{GHG emissions $\left(\mathrm{CO}_{2} \mathrm{e}\right)$}

- Vehicle manufacturing emissions (inc. battery production)

Well-to-wheel emissions

Maintenance emissions (inc. battery replacements)

- Infrastructure manufacture and maintenance emissions

Whole life cycle GHG emissions

Figure 4. Life-cycle model. 


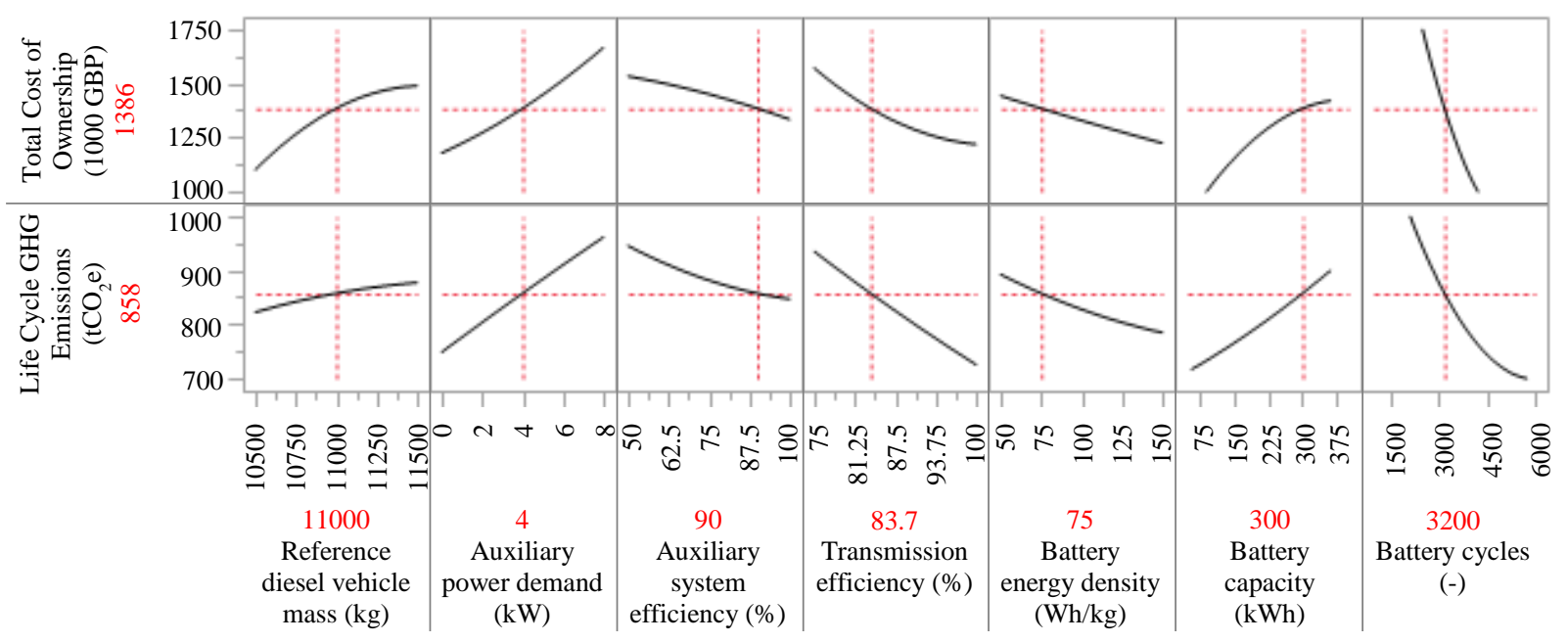

Figure 5. Sample of the TIF prediction profile environment generated for this study in JMP® [85]. 

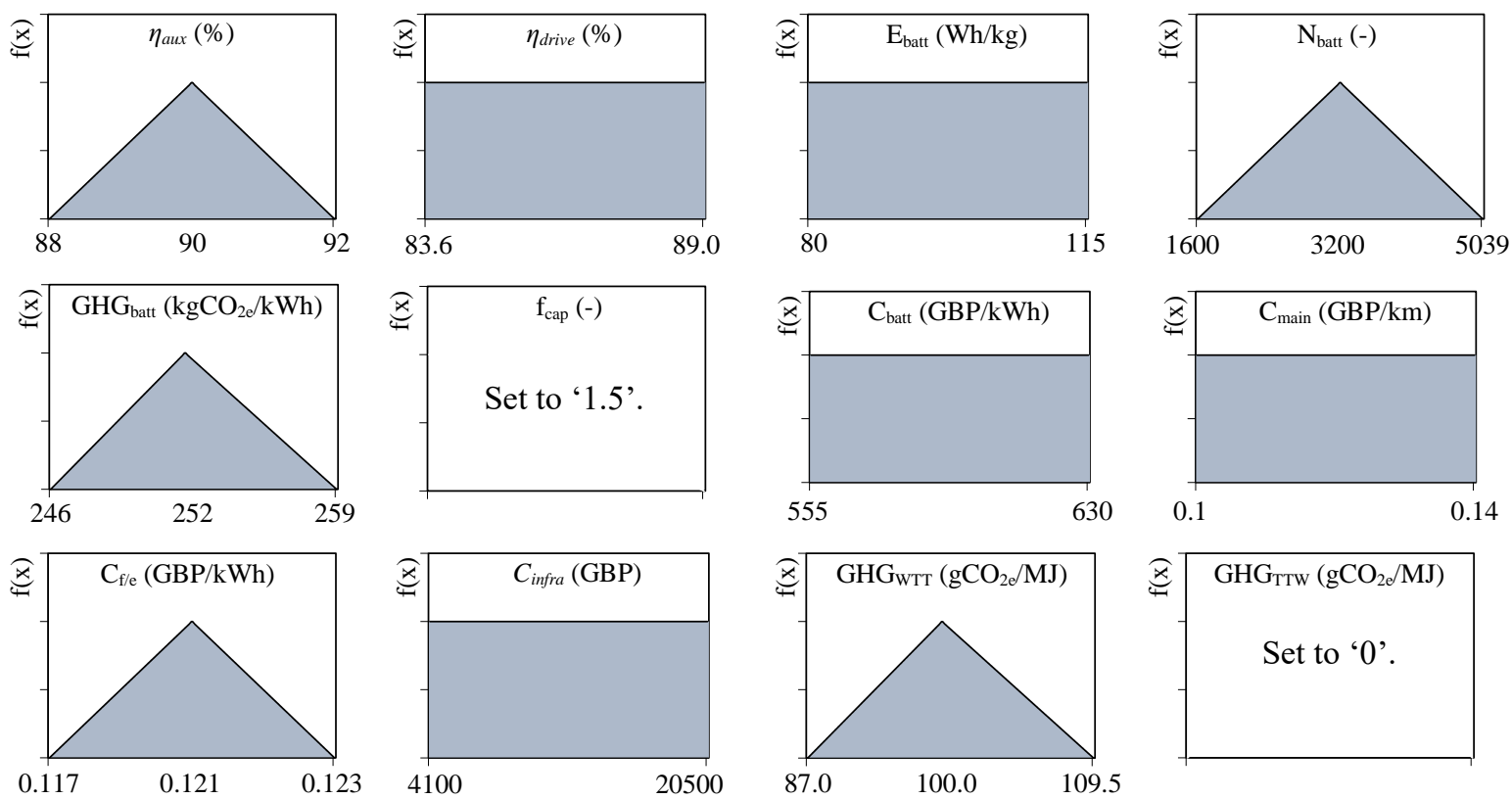

Figure 6. $k \_$factor distributions for the LFP BEB (UK grid) technology scenario. 


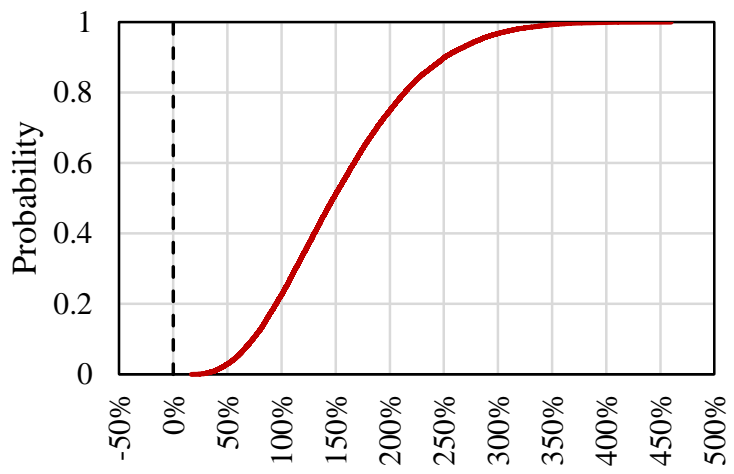

Total Cost of Ownership - \% deviation from baseline

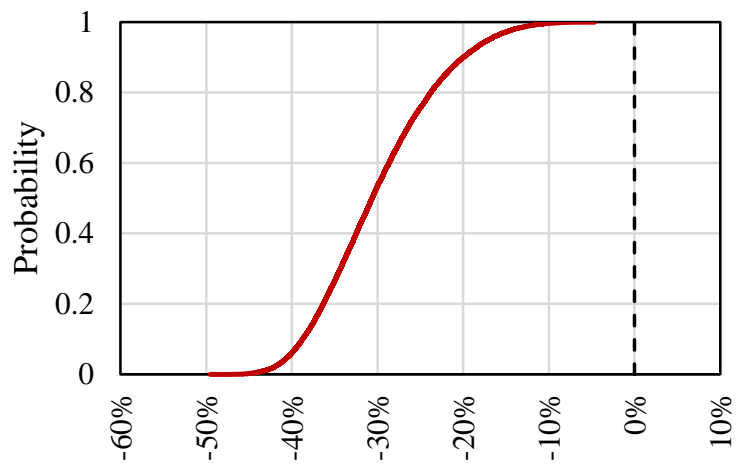

Life Cycle GHG Emissions - \% deviation from baseline

Figure 7. CDF plots for the LFP BEB (UK Grid) technology scenario. 


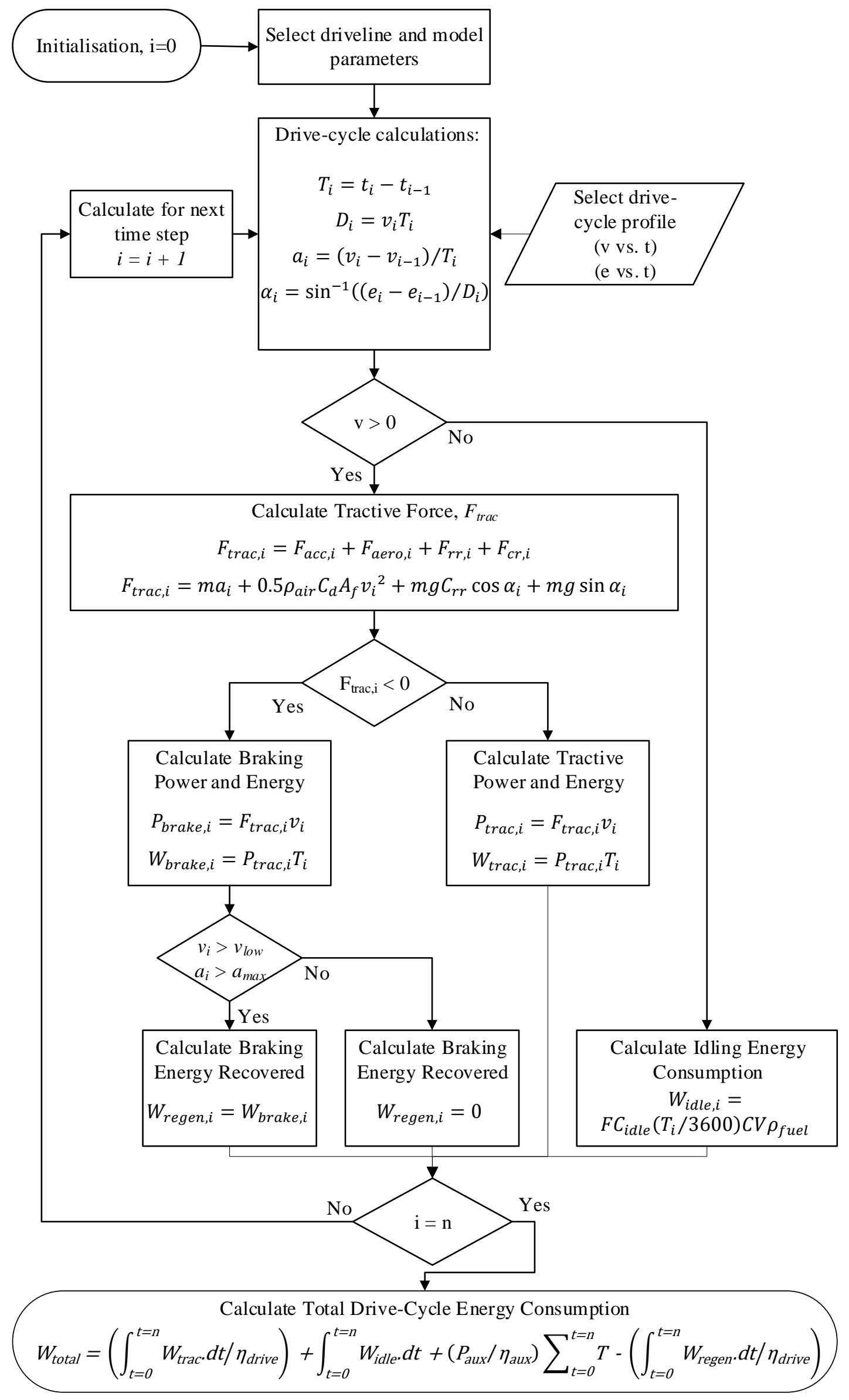

Figure A1. Algorithm for calculating drive-cycle energy demand. Terms defined in Appendix A. 
Table 1. Life cycle analysis terminology.

\begin{tabular}{ll}
\hline \multicolumn{1}{c}{ Term } & \multicolumn{1}{c}{ Description } \\
\hline $\begin{array}{l}\text { Life cycle } \\
\text { analysis (LCA) }\end{array}$ & $\begin{array}{l}\text { A methodology which addresses the potential environmental impacts throughout } \\
\text { a product's life cycle from raw material acquisition through production, use and } \\
\text { end-of-life treatment [26,27]. }\end{array}$ \\
$\begin{array}{ll}\text { Well-to-wheels } \\
\text { (WTW) analysis }\end{array}$ & $\begin{array}{l}\text { The dominant LCA approach for comparing alternative vehicle technologies. } \\
\text { Widely used for policy support in road transport [28]. Focuses on the processes } \\
\text { of the energy carrier (i.e. diesel or electricity) used to propel the vehicle during } \\
\text { operation. Comprises the well-to-tank (WTT) and tank-to-wheel (TTW) phases. }\end{array}$ \\
$\begin{array}{ll}\text { Well-to-tank } \\
\text { (WTT) analysis }\end{array}$ & $\begin{array}{l}\text { Comprises the recovery or production of the feedstock for the energy carrier and } \\
\text { subsequent energy conversion, delivery/transmission and storage. }\end{array}$ \\
$\begin{array}{l}\text { Tank-to-wheels } \\
\text { (TTW) analysis }\end{array}$ & $\begin{array}{l}\text { Comprises the on-board energy conversion to drive the vehicle based on the } \\
\text { lifetime distance travelled, fuel energy required and vehicle efficiency [29]. }\end{array}$ \\
\hline
\end{tabular}


Table 2. Values obtained from the UK EIO-LCA model (adjusted for 2016 costs).

\begin{tabular}{lll}
\hline & & GHG Emissions produced per \\
SIC & Sector Description & GBP demand $\left(\mathrm{kgCO}_{2} \mathrm{e} / \mathrm{GBP}\right)$ \\
\hline 29 & Manufacture of motor vehicles, trailers and semi-trailers & 0.630 \\
45 & Repair services of motor vehicles and motorcycles & 0.247 \\
27 & Manufacture of electrical equipment & 0.539 \\
33 & Rest of repair & 0.273 \\
\hline
\end{tabular}


Table 3. Battery technology characteristics.

\begin{tabular}{ccccc}
\hline $\begin{array}{c}\text { Energy } \\
\text { Storage } \\
\text { Type }\end{array}$ & $\begin{array}{c}\text { Specific } \\
\text { Energy, } E_{\text {batt }} \\
(\mathrm{Wh} / \mathrm{kg})\end{array}$ & $\begin{array}{c}\text { Cycles, } \\
N_{\text {batt }}\end{array}$ & $\begin{array}{c}\text { Estimated Pack Cost } \\
\text { per kWh, } C_{\text {batt }} \\
(\mathrm{USD} / \mathrm{kWh})\end{array}$ & $\begin{array}{c}\text { Estimated Production } \\
\text { emissions, } G H G_{\text {batt }} \\
\left(\mathrm{kgCO}_{2} \mathrm{e} / \mathrm{kWh}\right)\end{array}$ \\
\hline NMC & $75-170^{\mathrm{a}}$ & $1000-3000^{\mathrm{a}}$ & $750-850^{\mathrm{b}}$ & $248-267^{\mathrm{a}}$ \\
LFP & $80-115^{\mathrm{a}}$ & $1600-5039^{\mathrm{a}}$ & $900-1540^{\mathrm{b}, \mathrm{c}}$ & $246-259^{\mathrm{a}}$ \\
LTO & $45-100^{\mathrm{a}}$ & $2000-6800^{\mathrm{a}}$ & $1500-2000^{\mathrm{b}}$ & $254-279^{\mathrm{a}}$ \\
\hline
\end{tabular}

${ }^{\mathrm{a}}$ Values correspond to electric vehicle traction batteries from [68].

${ }^{\mathrm{b}}$ Reported battery pack costs for bus applications from [69].

${ }^{\mathrm{c}}$ Converted at rate of 0.81 Euros per USD from [70]. 
Table 4. Driveline technology variables, baseline values and ranges of variability studied.

\begin{tabular}{|c|c|c|c|}
\hline \multirow[b]{2}{*}{$k_{-}$factor (variable of interest) } & \multirow{2}{*}{$\begin{array}{l}\text { Baseline } \\
\text { value }\end{array}$} & \multicolumn{2}{|c|}{ Deviation from baseline } \\
\hline & & Lower & Upper \\
\hline Reference diesel vehicle tare mass, $m(\mathrm{~kg})$ & 11,000 & $0 \%$ & $+5 \%$ \\
\hline Auxiliary power demand, $P_{a u x}(\mathrm{~kW})$ & 4 & $0 \%$ & $+100 \%$ \\
\hline Auxiliary system efficiency, $\eta_{\text {aux }}(\%)$ & $60 \%{ }^{\mathrm{a}}$ & $0 \%$ & $+53 \%$ \\
\hline Drivetrain efficiency, $\eta_{\text {drive }}(\%)$ & $76.8 \%{ }^{\mathrm{b}}$ & $0 \%$ & $+16 \%$ \\
\hline Battery capacity, $\mathrm{Q}_{\text {batt }}(\mathrm{kWh})$ & $0^{\mathrm{c}}$ & 0 & 300 \\
\hline Battery specific energy, $E_{\text {batt }}(\mathrm{Wh} / \mathrm{kg})$ & $0^{\mathrm{c}}$ & 0 & 170 \\
\hline Battery cycles, $N_{\text {batt }}(-)$ & $0^{\mathrm{c}}$ & 0 & 5039 \\
\hline Battery production emissions, $G H G_{\text {batt }}\left(\mathrm{kgCO}_{2} \mathrm{e} / \mathrm{kWh}\right)$ & $0^{\mathrm{c}}$ & 0 & 300 \\
\hline Capital cost factor (exc. battery), $f_{\text {cap }}(-)$ & 1 & $0 \%$ & $+50 \%$ \\
\hline Battery pack cost per kWh, $C_{\text {batt }}(\mathrm{GBP} / \mathrm{kWh})$ & $0^{\mathrm{c}}$ & 0 & 1480 \\
\hline Maintenance cost per km, $C_{\text {main }}(\mathrm{GBP} / \mathrm{km})$ & $0.16^{\mathrm{d}}$ & $-38 \%$ & $+10 \%$ \\
\hline Energy cost per kWh, $C_{f / e}(\mathrm{GBP} / \mathrm{kWh})$ & $0.054^{\mathrm{e}}$ & $-7 \%$ & $+44 \%$ \\
\hline Infrastructure cost per bus, $C_{\text {infra }}(\mathrm{GBP})$ & $1199^{f}$ & $0 \%$ & $+9093 \%$ \\
\hline WTT GHG emissions, $G H G_{W T T}\left(\mathrm{gCO}_{2} \mathrm{e} / \mathrm{MJ}\right)$ & $15.4^{\mathrm{e}}$ & $-87 \%$ & $+878 \%$ \\
\hline TTW GHG emissions, $G H G_{T T W}\left(\mathrm{gCO}_{2} \mathrm{e} / \mathrm{MJ}\right)$ & $76.2^{\mathrm{e}}$ & $-100 \%$ & $+15 \%$ \\
\hline
\end{tabular}

${ }^{a}$ Assumed alternator efficiency [73].

${ }^{\mathrm{b}}$ Sum of clutch, gearbox, final drive and wheel efficiencies from [64].

${ }^{\mathrm{c}}$ Traditionally in TIF studies, percentage deviations from the baseline are used, this study also includes variability of inputs applicable to BEBs only.

${ }^{\mathrm{d}}$ Converted at a rate of 0.82 GBP per Euro from [6],

e See Table 5.

${ }^{\mathrm{f}}$ Calculated based on lifetime diesel consumption and operation \& maintenance cost used in [74]. 
Table 5. GHG Emissions coefficients and energy costs used in the life cycle model.

\begin{tabular}{llllllllll}
\hline & \multicolumn{3}{c}{$G H G_{W T T}\left(\mathrm{gCO}_{2} \mathrm{e} / \mathrm{MJ}\right)$} & \multicolumn{2}{c}{$G H G_{T T W}\left(\mathrm{gCO}_{2} \mathrm{e} / \mathrm{MJ}\right)$} & \multicolumn{2}{c}{$\mathrm{C}_{\mathrm{f} / \mathrm{e}}(G B P / k W h)$} & \\
& Min & Mean & Max & Min & Mean & Max & Min & Mean & Max \\
\hline Diesel & $13.8^{\mathrm{a}}$ & $15.4^{\mathrm{a}}$ & $17^{\mathrm{a}}$ & $75.7^{\mathrm{d}}$ & $76.2^{\mathrm{d}}$ & $76.5^{\mathrm{d}}$ & $0.046^{\mathrm{e}}$ & $0.054^{\mathrm{e}}$ & $0.061^{\mathrm{e}}$ \\
Electricity (UK grid) & $87.0^{\mathrm{b}}$ & $100.0^{\mathrm{b}}$ & $109.5^{\mathrm{b}}$ & 0 & 0 & 0 & $0.117^{\mathrm{f}}$ & $0.121^{\mathrm{f}}$ & $0.123^{\mathrm{f}}$ \\
Electricity (wind) & $1.94^{\mathrm{c}}$ & $3.06^{\mathrm{c}}$ & $15.6^{\mathrm{c}}$ & 0 & 0 & 0 & $0.050^{\mathrm{g}}$ & $0.067^{\mathrm{g}}$ & $0.081^{\mathrm{g}}$ \\
\hline
\end{tabular}

${ }^{a}$ Crude oil production, transport, refining into diesel fuel, distribution and dispensing on site [76].

${ }^{\mathrm{b}}$ Calculated using 2016 emissions data from [77] and transmission losses in the UK grid [78].

${ }^{c}$ Values obtained from [79].

${ }^{\mathrm{d}}$ Calculated using energy and emission results of a representative Euro VI diesel engine [80].

${ }^{\mathrm{e}}$ Weekly road fuel price 2016 excluding VAT and a fuel duty rebate of 0.3457 GBP per L [81,82].

${ }^{\mathrm{f}}$ Average annual 2016 UK electricity cost assuming small consumer size and includes Climate Change Levy [83].

g Values obtained from [84]. 
Table 6. Comparison of results with $80 \%$ probability for all ten technology scenarios.

\begin{tabular}{|c|c|c|c|c|c|c|c|c|c|c|c|c|}
\hline \multirow[b]{2}{*}{$\begin{array}{l}\text { Drivetrain/Battery } \\
\text { configuration }\end{array}$} & \multirow{2}{*}{$\begin{array}{l}\begin{array}{l}\text { Baseline } \\
\text { result }\end{array} \\
\text { Diesel }\end{array}$} & \multicolumn{3}{|c|}{ UK grid scenarios } & \multicolumn{3}{|c|}{ Wind scenarios } & \multicolumn{3}{|c|}{$\begin{array}{l}\text { Opportunity charging } \\
\text { scenarios }\end{array}$} & \multicolumn{2}{|c|}{ HVAC scenarios } \\
\hline & & $\mathrm{NMC}^{\mathrm{a}}$ & $\mathrm{LFP}^{\mathrm{a}}$ & $\mathrm{LTO}^{\mathrm{a}}$ & $\mathrm{NMC}^{\mathrm{a}}$ & LFP $^{\mathrm{a}}$ & $\mathrm{LTO}^{\mathrm{a}}$ & $\mathrm{NMC}^{\mathrm{a}}$ & LFP $^{\mathrm{a}}$ & $\mathrm{LTO}^{\mathrm{a}}$ & $\mathrm{LFP}^{\mathrm{a}}$ & Diesel \\
\hline Costs (1000 GBP) & & \multicolumn{11}{|c|}{${ }^{\mathrm{d}}$ Costs $\%$ deviation from baseline value ( $80 \%$ probability) } \\
\hline Vehicle acquisition & 190.0 & $+147 \%$ & $+198 \%$ & $+255 \%$ & $+147 \%$ & $+198 \%$ & $+255 \%$ & $+69 \%$ & $+80 \%$ & $+91 \%$ & $+209 \%$ & $+8 \%$ \\
\hline Fuel/Energy & 269.5 & $-41 \%$ & $-40 \%$ & $-38 \%$ & $-66 \%$ & $-65 \%$ & $-64 \%$ & $-49 \%$ & $-48 \%$ & $-47 \%$ & $-32 \%$ & $+19 \%$ \\
\hline${ }^{\mathrm{b}}$ Maintenance & 119.6 & $+936 \%$ & $+822 \%$ & $+889 \%$ & $+948 \%$ & $+821 \%$ & $+878 \%$ & $+642 \%$ & $+546 \%$ & $+599 \%$ & $+1032 \%$ & $+7 \%$ \\
\hline${ }^{\mathrm{c}}$ Infrastructure & 1.2 & $+2046 \%$ & $+2050 \%$ & $+2038 \%$ & $+2354 \%$ & $+2340 \%$ & $+2039 \%$ & $+9681 \%$ & $+9682 \%$ & $+9640 \%$ & $+2340 \%$ & $+0 \%$ \\
\hline TCO & 580.2 & $+221 \%$ & $+214 \%$ & $+247 \%$ & $+212 \%$ & $+201 \%$ & $+231 \%$ & $+145 \%$ & $+129 \%$ & $+144 \%$ & $+264 \%$ & $+13 \%$ \\
\hline \multicolumn{2}{|c|}{ GHG Emissions $\left(\mathrm{tCO}_{2} \mathrm{e}\right)$} & \multicolumn{11}{|c|}{${ }^{\mathrm{d}}$ GHG Emissions \% deviation from baseline value ( $\mathbf{8 0 \%}$ probability) } \\
\hline Manufacturing & 119.8 & $+115 \%$ & $+114 \%$ & $+117 \%$ & $+115 \%$ & $+114 \%$ & $+117 \%$ & $+63 \%$ & $+63 \%$ & $+63 \%$ & $+124 \%$ & $+8 \%$ \\
\hline WTW & 992.9 & $-65 \%$ & $-65 \%$ & $-63 \%$ & $-97 \%$ & $-97 \%$ & $-96 \%$ & $-70 \%$ & $-69 \%$ & $-69 \%$ & $-60 \%$ & $+20 \%$ \\
\hline${ }^{\mathrm{b}}$ Maintenance & 24.3 & $+1692 \%$ & $+1021 \%$ & $+673 \%$ & $+1714 \%$ & $+1035 \%$ & $+669 \%$ & $+1607 \%$ & $+935 \%$ & $+563 \%$ & $+1225 \%$ & $+32 \%$ \\
\hline${ }^{\mathrm{C}}$ Infrastructure & 0.3 & $+4135 \%$ & $+4144 \%$ & $+4121 \%$ & $+4743 \%$ & $+4716 \%$ & $+4122 \%$ & $+19206 \%$ & $+19208 \%$ & $+19125 \%$ & $+4716 \%$ & $+0 \%$ \\
\hline Life cycle & 1137.2 & $-10 \%$ & $-24 \%$ & $-30 \%$ & $-37 \%$ & $-51 \%$ & $-58 \%$ & $-18 \%$ & $-32 \%$ & $-39 \%$ & $-14 \%$ & $+19 \%$ \\
\hline $\begin{array}{l}\text { Additional cost increase } \\
\text { per } \mathrm{kgCO}_{2} \mathrm{e} \text { mitigated } \\
\left(\mathrm{GBP} / \mathrm{kgCO}_{2} \mathrm{e}\right)\end{array}$ & - & +11.29 & +4.59 & +4.21 & +2.96 & +2.01 & +2.04 & +4.15 & +2.05 & +1.86 & +9.33 & -0.30 \\
\hline
\end{tabular}


Table B.1 Shape Functions used in each Technology Scenario.

\begin{tabular}{|c|c|c|c|c|c|c|c|c|c|c|c|c|}
\hline & $\begin{array}{l}\text { Baseline } \\
\text { value }^{\mathrm{a}}\end{array}$ & UK Grid Sc & cenarios & & Wind Scens & arios & & Opportunity & y Charging $\mathrm{S}$ & Scenarios & HVAC Sce & narios \\
\hline configuration & Diesel & $\mathrm{NMC}$ & LFP & LTO & NMC & LFP & LTO & NMC & LFP & LTO & LFP & Diesel \\
\hline $\begin{array}{l}\text { Reference diesel } \\
\text { vehicle mass, } \\
m(\mathrm{~kg})\end{array}$ & 11000 & - & - & - & - & - & - & - & - & - & 11500 & 11500 \\
\hline $\begin{array}{l}\text { Auxiliary power } \\
\text { demand, } \\
P_{a u x}(\mathrm{~kW})\end{array}$ & 4 & - & - & - & - & - & - & - & - & - & $\begin{array}{l}\text { Triangular } \\
\text { Min: } 4 \\
\text { Cen: } 8 \\
\text { Max: } 8\end{array}$ & $\begin{array}{l}\text { Triangular } \\
\text { Min: } 4 \\
\text { Cen: } 8 \\
\text { Max: } 8\end{array}$ \\
\hline $\begin{array}{l}\text { Auxiliary system } \\
\text { efficiency, } \\
\eta_{\text {aux }}(\%)\end{array}$ & 60 & $\begin{array}{l}\text { Triang. } \\
\text { Min: } 88 \\
\text { Cen: } 90 \\
\text { Max: } 92 \\
\end{array}$ & $\begin{array}{l}\text { Triang. } \\
\text { Min: } 88 \\
\text { Cen: } 90 \\
\text { Max: } 92 \\
\end{array}$ & $\begin{array}{l}\text { Triang. } \\
\text { Min: } 88 \\
\text { Cen: } 90 \\
\text { Max: } 92 \\
\end{array}$ & $\begin{array}{l}\text { Triang. } \\
\text { Min: } 88 \\
\text { Cen: } 90 \\
\text { Max: } 92 \\
\end{array}$ & $\begin{array}{l}\text { Triang. }^{\text {b }} \\
\text { Min: } 88 \\
\text { Cen: } 90 \\
\text { Max: } 92\end{array}$ & $\begin{array}{l}\text { Triang. } \\
\text { Min: } 88 \\
\text { Cen: } 90 \\
\text { Max: } 92\end{array}$ & $\begin{array}{l}\text { Triang. }{ }^{\mathrm{b}} \\
\text { Min: } 88 \\
\text { Cen: } 90 \\
\text { Max: } 92\end{array}$ & $\begin{array}{l}\text { Triang. } \\
\text { Min: } 88 \\
\text { Cen: } 90 \\
\text { Max: } 92\end{array}$ & $\begin{array}{l}\text { Triang. } \\
\text { Min: } 88 \\
\text { Cen: } 90 \\
\text { Max: } 92 \\
\end{array}$ & $\begin{array}{l}\text { Triang. } \\
\text { Min: } 88 \\
\text { Cen: } 90 \\
\text { Max: } 92\end{array}$ & 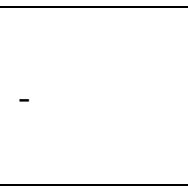 \\
\hline $\begin{array}{l}\text { Drivetrain } \\
\text { efficiency, } \\
\eta_{\text {trans }}(\%) \\
\end{array}$ & 76.8 & $\begin{array}{l}\text { Uniform }^{c} \\
\text { Min: } 83.6 \\
\text { Max: } 89 \\
\end{array}$ & $\begin{array}{l}\text { Uniform }^{c} \\
\text { Min: } 83.6 \\
\text { Max: } 89\end{array}$ & $\begin{array}{l}\text { Uniform }^{\mathrm{c}} \\
\text { Min: } 83.6 \\
\text { Max: } 89\end{array}$ & $\begin{array}{l}\text { Uniform }^{\mathrm{c}} \\
\text { Min: } 83.6 \\
\text { Max: } 89\end{array}$ & $\begin{array}{l}\text { Uniform }^{\mathrm{c}} \\
\text { Min: } 83.6 \\
\text { Max: } 89\end{array}$ & $\begin{array}{l}\text { Uniform }^{\mathrm{c}} \\
\text { Min: } 83.6 \\
\text { Max: } 89 \\
\end{array}$ & $\begin{array}{l}\text { Uniform }^{c} \\
\text { Min: } 83.6 \\
\text { Max: } 89 \\
\end{array}$ & $\begin{array}{l}\text { Uniform }^{\mathrm{c}} \\
\text { Min: } 83.6 \\
\text { Max: } 89 \\
\end{array}$ & $\begin{array}{l}\text { Uniform }^{c} \\
\text { Min: } 83.6 \\
\text { Max: } 89 \\
\end{array}$ & $\begin{array}{l}\text { Uniform }^{\mathrm{c}} \\
\text { Min: } 83.6 \\
\text { Max: } 89\end{array}$ & - \\
\hline $\begin{array}{l}\text { Battery energy } \\
\text { density, } \\
E_{\text {batt }}(\mathrm{Wh} / \mathrm{kg})\end{array}$ & 0 & $\begin{array}{l}\text { Uniform }^{\mathrm{d}} \\
\text { Min: } 75 \\
\text { Max: } 170\end{array}$ & $\begin{array}{l}\text { Uniform }^{\mathrm{d}} \\
\text { Min: } 80 \\
\text { Max: } 115\end{array}$ & $\begin{array}{l}\text { Uniform }^{\mathrm{d}} \\
\text { Min: } 45 \\
\text { Max: } 100\end{array}$ & $\begin{array}{l}\text { Uniform }^{\mathrm{d}} \\
\text { Min: } 75 \\
\text { Max: } 170 \\
\end{array}$ & $\begin{array}{l}\text { Uniform }^{\mathrm{d}} \\
\text { Min: } 80 \\
\text { Max: } 115\end{array}$ & $\begin{array}{l}\text { Uniform }^{\mathrm{d}} \\
\text { Min: } 45 \\
\text { Max: } 100\end{array}$ & $\begin{array}{l}\text { Uniform }^{\mathrm{d}} \\
\text { Min: } 75 \\
\text { Max: } 170\end{array}$ & $\begin{array}{l}\text { Uniform }^{\mathrm{d}} \\
\text { Min: } 80 \\
\text { Max: } 115\end{array}$ & $\begin{array}{l}\text { Uniform }^{\mathrm{d}} \\
\text { Min: } 45 \\
\text { Max: } 100\end{array}$ & $\begin{array}{l}\text { Uniform }^{\mathrm{d}} \\
\text { Min: } 80 \\
\text { Max: } 115\end{array}$ & - \\
\hline $\begin{array}{l}\text { Battery capacity, } \\
Q_{\text {batt }}(\mathrm{kWh})\end{array}$ & 0 & 300 & 300 & 300 & 300 & 300 & 300 & 60 & 60 & 60 & 300 & - \\
\hline $\begin{array}{l}\text { Battery cycles, } \\
N_{\text {batt }}(-)\end{array}$ & 0 & $\begin{array}{l}\text { Triang. } \\
\text { Min: } 1000 \\
\text { Cen: } 1700 \\
\text { Max: } 3000\end{array}$ & $\begin{array}{l}\text { Triang. } \\
\text { Min: } 1600 \\
\text { Cen: } 3200 \\
\text { Max: } 5039\end{array}$ & $\begin{array}{l}\text { Triang. } \\
\text { Min: } 2000 \\
\text { Cen: } 5000 \\
\text { Max: } 6800\end{array}$ & $\begin{array}{l}\text { Triang. } \\
\text { Min: } 1000 \\
\text { Cen: } 1700 \\
\text { Max: } 3000\end{array}$ & $\begin{array}{l}\text { Triang. } \\
\text { Min: } 1600 \\
\text { Cen: } 3200 \\
\text { Max: } 5039\end{array}$ & $\begin{array}{l}\text { Triang. }{ }^{\mathrm{d}} \\
\text { Min: } 2000 \\
\text { Cen: } 5000 \\
\text { Max: } 6800\end{array}$ & $\begin{array}{l}\text { Triang. }{ }^{\mathrm{d}} \\
\text { Min: } 1000 \\
\text { Cen: } 1700 \\
\text { Max: } 3000\end{array}$ & $\begin{array}{l}\text { Triang. } \\
\text { Min: } 1600 \\
\text { Cen: } 3200 \\
\text { Max: } 5039\end{array}$ & $\begin{array}{l}\text { Triang. } \\
\text { Min: } 2000 \\
\text { Cen: } 5000 \\
\text { Max: } 6800\end{array}$ & $\begin{array}{l}\text { Triang. } \\
\text { Min: } 1600 \\
\text { Cen: } 3200 \\
\text { Max: } 5039\end{array}$ & \\
\hline
\end{tabular}




\begin{tabular}{|c|c|c|c|c|c|c|c|c|c|c|c|c|}
\hline $\begin{array}{l}\text { GHG emissions per } \\
\text { kg-battery, } \\
\text { GHG }{ }_{\text {batt }} \\
\left(\mathrm{kgCO}_{2} \mathrm{e} / \mathrm{kWh}\right)\end{array}$ & 0 & $\begin{array}{l}\text { Triang. }{ }^{\mathrm{d}} \\
\text { Min: } 248 \\
\text { Cen: } 254 \\
\text { Max: } 267\end{array}$ & $\begin{array}{l}\text { Triang. }{ }^{\mathrm{d}} \\
\text { Min: } 246 \\
\text { Cen: } 252 \\
\text { Max: } 259\end{array}$ & $\begin{array}{l}\text { Triang. }{ }^{\mathrm{d}} \\
\text { Min: } 254 \\
\text { Cen: } 260 \\
\text { Max: } 279\end{array}$ & $\begin{array}{l}\text { Triang. }{ }^{\mathrm{d}} \\
\text { Min: } 248 \\
\text { Cen: } 254 \\
\text { Max: } 267\end{array}$ & $\begin{array}{l}\text { Triang. }^{\mathrm{d}} \\
\text { Min: } 246 \\
\text { Cen: } 252 \\
\text { Max: } 259\end{array}$ & $\begin{array}{l}\text { Triang. } \\
\text { Min: } 254 \\
\text { Cen: } 260 \\
\text { Max: } 279\end{array}$ & $\begin{array}{l}\text { Triang. }^{\mathrm{d}} \\
\text { Min: } 248 \\
\text { Cen: } 254 \\
\text { Max: } 267\end{array}$ & $\begin{array}{l}\text { Triang. }{ }^{\mathrm{d}} \\
\text { Min: } 246 \\
\text { Cen: } 252 \\
\text { Max: } 259\end{array}$ & $\begin{array}{l}\text { Triang. } \\
\text { Min: } 254 \\
\text { Cen: } 260 \\
\text { Max: } 279\end{array}$ & $\begin{array}{l}\text { Triang. }{ }^{\mathrm{d}} \\
\text { Min: } 246 \\
\text { Cen: } 252 \\
\text { Max: } 259\end{array}$ & - \\
\hline $\begin{array}{l}\text { Capital cost factor } \\
\text { (exc. BEB battery), } \\
C_{c a p}(-)\end{array}$ & 1 & $1.56^{\mathrm{e}}$ & $1.56^{\mathrm{e}}$ & $1.56^{\mathrm{e}}$ & $1.56^{\mathrm{e}}$ & $1.56^{\mathrm{e}}$ & $1.56^{\mathrm{e}}$ & $1.56^{\mathrm{e}}$ & $1.56^{\mathrm{e}}$ & $1.56^{\mathrm{e}}$ & $1.72^{\mathrm{f}}$ & $1.1^{\mathrm{f}}$ \\
\hline $\begin{array}{l}\text { Battery cost per } \\
\text { kWh, } C_{\text {batt }} \\
(\mathrm{GBP} / \mathrm{kWh})\end{array}$ & 0 & $\begin{array}{l}\text { Uniform }^{\mathrm{d}} \\
\text { Min: } 555 \\
\text { Max: } 630\end{array}$ & $\begin{array}{l}\text { Triang. } \\
\text { Min: } 666 \\
\text { Cen: } 725 \\
\text { Max: } 1140\end{array}$ & $\begin{array}{l}\text { Triang. }{ }^{\mathrm{d}} \\
\text { Min: } 1050 \\
\text { Cen: } 1110 \\
\text { Max: } 1480 \\
\end{array}$ & $\begin{array}{l}\text { Uniform }^{\mathrm{d}} \\
\text { Min: } 555 \\
\text { Max: } 630\end{array}$ & $\begin{array}{l}\text { Triang. } \\
\text { Min: } 666 \\
\text { Cen: } 725 \\
\text { Max: } 1140\end{array}$ & $\begin{array}{l}\text { Triang. }{ }^{\mathrm{d}} \\
\text { Min: } 1050 \\
\text { Cen: } 1110 \\
\text { Max: } 1480\end{array}$ & $\begin{array}{l}\text { Uniform }^{\mathrm{d}} \\
\text { Min: } 555 \\
\text { Max: } 630\end{array}$ & $\begin{array}{l}\text { Triang. }{ }^{\mathrm{d}} \\
\text { Min: } 666 \\
\text { Cen: } 725 \\
\text { Max: } 1140\end{array}$ & $\begin{array}{l}\text { Triang. }{ }^{\mathrm{d}} \\
\text { Min: } 1050 \\
\text { Cen: } 1110 \\
\text { Max: } 1480\end{array}$ & $\begin{array}{l}\text { Triang. }{ }^{\mathrm{d}} \\
\text { Min: } 666 \\
\text { Cen: } 725 \\
\text { Max: } 1140\end{array}$ & 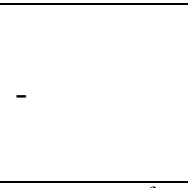 \\
\hline $\begin{array}{l}\text { Maintenance Cost } \\
\text { per km, } \\
C_{\text {main }}(\mathrm{GBP} / \mathrm{km}) \\
\end{array}$ & 0.16 & $\begin{array}{l}\text { Uniform }{ }^{\mathrm{g}} \\
\text { Min: } 0.1 \\
\text { Max: } 0.14\end{array}$ & $\begin{array}{l}\text { Uniform }{ }^{\mathrm{g}} \\
\text { Min: } 0.1 \\
\text { Max: } 0.14\end{array}$ & $\begin{array}{l}\text { Uniform }{ }^{\mathrm{g}} \\
\text { Min: } 0.1 \\
\text { Max: } 0.14 \\
\end{array}$ & $\begin{array}{l}\text { Uniform }^{\mathrm{g}} \\
\text { Min: } 0.1 \\
\text { Max: } 0.14\end{array}$ & $\begin{array}{l}\text { Uniform }^{\mathrm{g}} \\
\text { Min: } 0.1 \\
\text { Max: } 0.14\end{array}$ & $\begin{array}{l}\text { Uniform }^{\mathrm{g}} \\
\text { Min: } 0.1 \\
\text { Max: } 0.14\end{array}$ & $\begin{array}{l}\text { Uniform }^{\mathrm{g}} \\
\text { Min: } 0.1 \\
\text { Max: } 0.14\end{array}$ & $\begin{array}{l}\text { Uniform }{ }^{\mathrm{g}} \\
\text { Min: } 0.1 \\
\text { Max: } 0.14\end{array}$ & $\begin{array}{l}\text { Uniform }^{\mathrm{g}} \\
\text { Min: } 0.1 \\
\text { Max: } 0.14\end{array}$ & $\begin{array}{l}\text { Uniform }{ }^{\text {f,g }} \\
\text { Min: } 0.1 \\
\text { Max:0.154 }\end{array}$ & $\begin{array}{l}\text { Uniform }{ }^{\mathrm{f}} \\
\text { Min: } 0.16 \\
\text { Max:0.176 }\end{array}$ \\
\hline $\begin{array}{l}\text { Fuel/Energy cost } \\
\text { per kWh, } \\
C_{f / e}(\mathrm{GBP} / \mathrm{kWh})\end{array}$ & 0.054 & $\begin{array}{l}\text { Triang. } \\
\text { Min:0.117 } \\
\text { Cen:0.121 } \\
\text { Max:0.123 }\end{array}$ & $\begin{array}{l}\text { Triang. } \\
\text { Min:0.117 } \\
\text { Cen:0.121 } \\
\text { Max:0.123 }\end{array}$ & $\begin{array}{l}\text { Triang. } \\
\text { Min:0.117 } \\
\text { Cen:0.121 } \\
\text { Max:0.123 } \\
\end{array}$ & $\begin{array}{l}\text { Triang. } \\
\text { Min:0.050 } \\
\text { Cen:0.067 } \\
\text { Max:0.081 }\end{array}$ & $\begin{array}{l}\text { Triang. } \\
\text { Min:0.050 } \\
\text { Cen:0.067 } \\
\text { Max:0.081 }\end{array}$ & $\begin{array}{l}\text { Triang. } \\
\text { Min:0.050 } \\
\text { Cen:0.067 } \\
\text { Max:0.081 }\end{array}$ & $\begin{array}{l}\text { Triang. } \\
\text { Min:0.117 } \\
\text { Cen:0.121 } \\
\text { Max:0.123 }\end{array}$ & $\begin{array}{l}\text { Triang. } \\
\text { Min:0.117 } \\
\text { Cen:0.121 } \\
\text { Max:0.123 }\end{array}$ & $\begin{array}{l}\text { Triang. } \\
\text { Min:0.117 } \\
\text { Cen:0.121 } \\
\text { Max:0.123 }\end{array}$ & $\begin{array}{l}\text { Triang. } \\
\text { Min:0.117 } \\
\text { Cen:0.121 } \\
\text { Max:0.123 }\end{array}$ & \\
\hline $\begin{array}{l}\text { Infrastructure cost } \\
C_{\text {infra }}(1000 \mathrm{GBP})\end{array}$ & 1.119 & $\begin{array}{l}\text { Uniform }^{\mathrm{i}} \\
\text { Min: } 4.1 \\
\text { Max: } 20.5\end{array}$ & $\begin{array}{l}\text { Uniform }{ }^{\mathrm{i}} \\
\text { Min: } 4.1 \\
\text { Max: } 20.5\end{array}$ & $\begin{array}{l}\text { Uniform }^{\mathrm{i}} \\
\text { Min: } 4.1 \\
\text { Max: } 20.5\end{array}$ & $\begin{array}{l}\text { Uniform }^{\mathrm{i}} \\
\text { Min: } 4.1 \\
\text { Max: } 20.5\end{array}$ & $\begin{array}{l}\text { Uniform }^{\mathrm{i}} \\
\text { Min: } 4.1 \\
\text { Max: } 20.5\end{array}$ & $\begin{array}{l}\text { Uniform }^{\mathrm{i}} \\
\text { Min: } 4.1 \\
\text { Max: } 20.5\end{array}$ & $\begin{array}{l}\text { Triang. }{ }^{j} \\
\text { Min: } 24.1 \\
\text { Cen: } 51.7 \\
\text { Max: } 110.2\end{array}$ & $\begin{array}{l}\text { Triang. }{ }^{j} \\
\text { Min: } 24.1 \\
\text { Cen: } 51.7 \\
\text { Max: } 110.2\end{array}$ & $\begin{array}{l}\text { Triang. }{ }^{j} \\
\text { Min: } 24.1 \\
\text { Cen: } 51.7 \\
\text { Max: } 110.2\end{array}$ & $\begin{array}{l}\text { Uniform }^{\mathrm{i}} \\
\text { Min: } 4.1 \\
\text { Max: } 20.5\end{array}$ & - \\
\hline $\begin{array}{l}\text { Well-to-tank } \mathrm{GHG} \\
\text { emissions per } \mathrm{MJ}, \\
G H G_{W T T} \\
\left(\mathrm{gCO}_{2} \mathrm{e} / \mathrm{MJ}\right) \\
\end{array}$ & 15.4 & $\begin{array}{l}\text { Triang. } \\
\text { Min: } 87.0 \\
\text { Cen: } 100.0 \\
\text { Max: } 109.5\end{array}$ & $\begin{array}{l}\text { Triang. } \\
\text { Min: } 87.0 \\
\text { Cen: } 100.0 \\
\text { Max: } 109.5 \\
\end{array}$ & $\begin{array}{l}\text { Triang. } \\
\text { Min: } 87.0 \\
\text { Cen: } 100.0 \\
\text { Max:109.5 } \\
\end{array}$ & $\begin{array}{l}\text { Triang. } \\
\text { Min: } 1.94 \\
\text { Cen: } 3.06 \\
\text { Max: } 15.6 \\
\end{array}$ & $\begin{array}{l}\text { Triang. } \\
\text { Min: } 1.94 \\
\text { Cen: } 3.06 \\
\text { Max: } 15.6 \\
\end{array}$ & $\begin{array}{l}\text { Triang. } \\
\text { Min: } 1.94 \\
\text { Cen: } 3.06 \\
\text { Max: } 15.6\end{array}$ & $\begin{array}{l}\text { Triang. } \\
\text { Min: } 87.0 \\
\text { Cen: } 100.0 \\
\text { Max: } 109.5\end{array}$ & $\begin{array}{l}\text { Triang. } \\
\text { Min: } 87.0 \\
\text { Cen: } 100.0 \\
\text { Max: } 109.5 \\
\end{array}$ & $\begin{array}{l}\text { Triang. } \\
\text { Min: } 87.0 \\
\text { Cen: } 100.0 \\
\text { Max: } 109.5\end{array}$ & $\begin{array}{l}\text { Triang. } \\
\text { Min: } 87.0 \\
\text { Cen: } 100.0 \\
\text { Max:109.5 }\end{array}$ & \\
\hline $\begin{array}{l}\text { Tank-to-wheel } \\
\text { GHG emissions per } \\
\text { MJ, } G H G_{T T W} \\
\left(\mathrm{gCO}_{2} \mathrm{e} / \mathrm{MJ}\right)\end{array}$ & 76.2 & 0 & 0 & 0 & 0 & 0 & 0 & 0 & 0 & 0 & 0 & - \\
\hline
\end{tabular}

Abbreviations: Triang = triangular, $\min =$ minimum bound, cen = central value (most likely), max = maximum bound.

${ }^{\text {a }}$ See Table 4.

b Assumed DC-DC converter efficiency.

c Assumptions based on Gao et al. [64].

${ }^{\mathrm{d}}$ See Table 3. 
${ }^{\mathrm{e}}$ Calculated based on the ratio between the purchase cost of an electric bus (without battery) and diesel bus in Lajunen [49].

${ }^{\mathrm{f}}$ Assuming an additional $10 \%$ cost for the HVAC unit.

${ }^{\mathrm{g}}$ BEB maintenance costs excluding propulsion system converted at 0.74 GBP per USD [90].

${ }^{\mathrm{h}}$ See Table 5.

${ }^{\mathrm{i}}$ Converted at a rate of 0.82 GBP per Euro from [70].

${ }^{\mathrm{j}}$ Calculated from the infrastructure cost per bus for the baseline double decker bus scenarios in Kunith et al. [72]. 
Box 1. Creation of an EIO-LCA model [39,57].

The Leontif inverse equation (equation 1) relates changes in final demand, i.e. the value of a good or service (the price of the bus), to changes in monetary flows in the economy.

$\mathrm{X}=[I-A]^{-1} F$

The sum of environmental impact discharges is calculated using equation 2.

$B=R \cdot X=R[I-A]^{-1} F$

where, $X=$ sum of the total direct and indirect economic activity (GBP), I = identity matrix (-), A $=$ direct requirements matrix $(-), \mathrm{F}=$ change in final demand $(\mathrm{GBP}), \mathrm{B}=$ sum of environmental impact discharges $\left(\mathrm{kgCO}_{2} \mathrm{e}\right), \mathrm{R}=$ matrix of environmental discharge coefficients $\left(\mathrm{kgCO}_{2} \mathrm{e} / \mathrm{GBP}\right)$. 